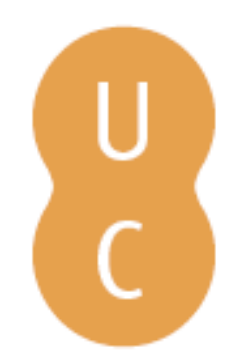

\title{
pompalina
}

\section{Ética e paideia em Plutarco}

Autor(es): $\quad$ Soares, Carmen Isabel Leal; Ferreira, José Ribeiro; Fialho, Maria do Céu

Publicado por: Centro de Estudos Clássicos e Humanísticos

URL

persistente: URI:http://hdl.handle.net/10316.2/2414

DOI: $\quad$ DOI:http://dx.doi.org/10.14195/978-989-721-062-4

Accessed : $\quad$ 26-Apr-2023 15:18:31

A navegação consulta e descarregamento dos títulos inseridos nas Bibliotecas Digitais UC Digitalis, UC Pombalina e UC Impactum, pressupõem a aceitação plena e sem reservas dos Termos e Condições de Uso destas Bibliotecas Digitais, disponíveis em https://digitalis.uc.pt/pt-pt/termos.

Conforme exposto nos referidos Termos e Condições de Uso, o descarregamento de títulos de acesso restrito requer uma licença válida de autorização devendo o utilizador aceder ao(s) documento(s) a partir de um endereço de IP da instituição detentora da supramencionada licença.

Ao utilizador é apenas permitido o descarregamento para uso pessoal, pelo que o emprego do(s) título(s) descarregado(s) para outro fim, designadamente comercial, carece de autorização do respetivo autor ou editor da obra.

Na medida em que todas as obras da UC Digitalis se encontram protegidas pelo Código do Direito de Autor e Direitos Conexos e demais legislação aplicável, toda a cópia, parcial ou total, deste documento, nos casos em que é legalmente admitida, deverá conter ou fazer-se acompanhar por este aviso. 
Colecção Autores Gregos e Latinos SérIe ENSAIOS

\section{Carmen Soares \\ José Ribeiro Ferreira Maria do Céu Fialho}

Ética e Paideia em Plutarco 
Volume integrado no projecto

Plutarco e os fundamentos da identidade europeia

e financiado pela Fundação para a Ciência e a Tecnologia.

Investigador responsável pelo projecto: Delfim Ferreira Leão. 


\section{Carmen Soares}

Universidade de Coimbra

\section{José Ribeiro Ferreira}

Universidade de Coimbra

Maria do Céu Fialho

Universidade de Coimbra

\section{Ética e Paideia em Plutarco}




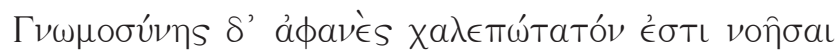

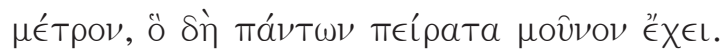
Sólon, frg. 16 West

À Prof. Doutora Maria Helena da Rocha Pereira, mestre dilecta, incansável no seu labor e olhar atento. 
Autores: Carmen Soares, José Rubeiro Ferreira, Maria do Céu Fualho Título: Ética e Paideia em Plutarco Editor: Centro de Estudos Clássicos e Humanísticos EDIÇĀO: 1a / 2008 Concepção Gráfica: Rodolfo Lopes

Obra REALizada no Âmbito das actividades da UI\&D Centro de Estudos Clássicos e Humanísticos

\author{
Universidade de Coimbra \\ FaCuldade de Letras \\ TeL.: 239859981 | Fax: 239836733 \\ 3000-447 CoImbra
}

ISBN: 978-989-8281-00-5

ISBN DigITAL: 978-989-721-062-4

DOI: http://dx.doi.org/10.14195/978-989-721-062-4

Depósito Legal: 278950/08

Obra Publicada com o Apoio de:

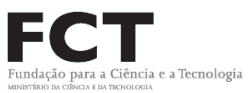

\title{
SoPlutarco
}

Sociedade Portuguesa de Plutarco

$\mathrm{POCI} / 2010$ 


\section{ÍNDICE}

IN LIMINE

Delfim F. Leấo

Maria do Céu Fialho

Philanthropia e Philautia no Teseu de Plutarco

Maria do Céu Fialho

Sócrates e a Paideia Falhada de Alcibíades

Maria do Céu Fialho

Decadência na Corte Persa: Um Soberano Inconstante e Uma Rainha-Mãe Vingativa na VIDA DE ARTAXERXES

Carmen Soares

Demotikos e demokratikos na paideia de Plutarco José Ribeiro Ferreira

O Doce Afago da Philanthropia

José Ribeiro Ferreira

Os Valores de Plutarco e sua Actualidade

José Ribeiro Ferreira

Bibliografia 


\section{IN LIMINE}

Sendo uma pessoa de origem grega e um indiscutível erudito, Plutarco de Queroneia partilhava também, e de forma compreensível, a noção da ascendência cultural da Hélade. Viveu, contudo, na viragem do séc. I para o séc. II da era cristá, portanto num período em que a Grécia se encontrava sob jugo romano. No entanto, em vez de essa contingência histórica inelutável motivar no biógrafo um sentimento de reacção contra os dominadores, levou-o antes a nutrir uma profunda admiração por Roma e a produzir uma extensa obra onde operou, como nenhum outro autor antigo, uma síntese admirável entre a Grécia e o Lácio, dando um contributo decisivo para estabelecer a noção de uma Antiguidade Clássica comum e para fixar as raízes culturais e identitárias que haveriam de marcar profundamente a construção da Europa. Recorrendo quer a retratos paralelos de ilustres figuras gregas e romanas, quer ainda a pequenos tratados onde aborda um riquíssimo leque de assuntos (desde o direito, a política e a religião, até à filosofia, ética e teorização literária), o polígrafo de Queroneia viria a exercer uma influência determinante no pensamento e literatura europeias, na escrita biográfica e na história das ideias, bem como em momentos de grandes mudanças políticas e sociais (como a revolução francesa).

Por este conjunto de razóes, pareceu importante aos investigadores envolvidos no projecto Plutarco e os fundamentos da identidade europeia trabalhar não apenas 
na tradução para português de tratados paradigmáticos das Vitae e dos Moralia de Plutarco, como ainda aprofundar o estudo das ideias e valores apresentados na obra do biógrafo e a sua repercussão na cultura e identidade europeias. Na sequência destes objectivos e em articulação com a coordenação do Centro de Estudos Clássicos e Humanísticos, em cujo plano de actividades se encontra integrado, este projecto acabou por estimular o lançamento de uma colecção de Autores Gregos e Latinos, com uma série de Textos e uma outra de Estudos. As Vidas Paralelas dos heróis fundadores, Teseu e Rómulo, foram escolhidas para abrir, simbolicamente, a série de traduçóes anotadas, enquanto o presente volume sobre Ética e paideia em Plutarco inaugura a parte dos ensaios. Porém, tanto a série de traduçóes como a de estudos deverão ser continuamente enriquecidas com novos contributos, que versem igualmente outros autores e temas, numa demonstração da influência constante que a Antiguidade Clássica exerceu e continua a exercer sobre o universo ideológico e cultural da civilização ocidental.

O INVESTIGADOR RESPONSÁVEL

A Coordenadora do CECH pelo projecto Plutarco 


\section{Philanthropia e Philautia no Teseu de Plutarco}

Já por si, a biografia inscreve-se num género literário marcado por uma natureza ambígua, entre a história e a ficção novelesca. ${ }^{1}$ Da história recebe a facticidade, da ficção aquilo que Aristóteles, na Poética, ${ }^{2}$ considera ser peculiar do discurso poético - o seu grau de universalidade. Esse, possui-o a História em grau muito inferior: ao narrar o particular, segundo o Estagirita, deixa lugar à Poesia para ser "mais filosófica". Assim, a biografia adequa-se a um fim didáctico e moralizante. Recorre ao factual da vida de figuras que, potencialmente, pode ser modelado de modo a converter o destino dessas figuras em exemplum, positivo ou negativo, para o leitor, mas marcado por um processo de universalização, análogo ao da poiesis. Assim transmite, retoricamente, convicçôes de fundo sobre história, vida política, padrôes éticos, de quem escreve a biografia para o receptor pressuposto na escrita.

No caso das Vidas Paralelas de Teseu e Rómulo, estamos, à partida, perante figuras de dois fundadores - elas são, de resto, as duas únicas biografias plutarquianas de fundadores, cuja existência se funde com as origens míticas das cidades a que estão ligados: Atenas e Roma. Plutarco tem consciência disto. Por isso mesmo, o proémio destas duas Vidas possui um carácter peculiar

${ }^{1}$ H. Bauzà 2002: 183.

2 1451b) 6-7. 
que lhe advém da peculiaridade destes dois heróis, pertencentes a épocas longínquas, incertas, que escapam ao rigor da informação histórica e que se tornam terreno propício à lenda e à efabulação. Aplicando um princípio que cultiva sistematicamente, Plutarco adverte o leitor, logo à partida, da metodologia que empregou: a de submeter, até onde lhe foi possível, to mythodes ao logos: ${ }^{3}$

Seja-me então lícito submeter a lenda (to mythodes) ao processo de expurgação que a razão (logos) opera, para que aquela assuma o aspecto de História (historias opsin).

O princípio cumpre-se, na biografia de Teseu, pela aplicação metodológica, por parte de Plutarco, de múltiplos processos de racionalização ao espólio de informaçóes e versóes tradicionais diversas de que dispõe. ${ }^{4}$

${ }^{3}$ Vit. Thes. 1.5 .

${ }^{4}$ Tais processos estáo enumerados e elucidados adequadamente em C. Ampolo 1993: xii ss.: quando Plutarco se confronta com duas versóes opostas segue a mais verosímil e mais atestada (o que o próprio escritor refere em Thes. 31,2) ; essa sua atitude leva-o a silenciar episódios famosos da vida de Teseu, ou a fazer uma alusão racionalizada, como acontece com muito do que respeita à expediçấo a Creta. A mesma restrição do maravilhoso ocorre com o episódio tradicional da descida ao Hades com Pirítoo, na mesma linha da tendência os atidógrafos. Por vezes, perante várias versôes igualmente verosímeis, Plutarco limita-se a reproduzi-las. É sistemática a desconfiança nos poetas, sobretudo cómicos, e, entre os trágicos, sobretudo Eurípides. A versão dos poetas só é aceite quando confirmada por outras fontes.

Um outro traço do racionalismo de Plutarco apontado por Ampolo é a sua preferência por versóes da tradição que se liguem à instituição de um culto testemunhado pela sua sobrevivência ou pela existência de lugares onde se celebrou no passado. Nota ainda Ampolo a preocupação plutarquiana em separar a acção divina da 
A contraposição, ao longo da Vita de Teseu, de fontes documentais, ou a enumeração das que se corroboram entre si atesta que Plutarco concebeu o prólogo dentro dos moldes retóricos próprios do intróito a obras históricas. ${ }^{5}$ Eles não só se inserem numa linha de racionalismo, como se destinam a proteger o seu autor de críticas de imprecisão.

Plutarco reconhece que a distância, no tempo, em que se perde a existência de Teseu contribui para obscurecer os acontecimentos remotos. A história de acontecimentos mais próximos, todavia, debate-se, com outras dificuldades. Uma delas consiste na distorção, subjectiva e premeditada, operada pelos poetas, nomeadamente pela actividade caricatural da comédia, ${ }^{6}$ conforme reconhece na Vida de Péricles, 13. 14-16, em franca alusão aos estragos operados pela comédia. Deste modo confessa, nesse mesmo passo:

Assim se vê até que ponto é árdua e difícil para o historiador a tarefa de apurar a verdade. Todo aquele que viver depois dos acontecimentos de que se ocupar conte sempre com a acçáo veladora do tempo a ocultar-lhe o conhecimento dos factos, mas a história de feitos e vidas de contemporâneos corrompe e distorce a verdade por ódios e malquerenças ou com o intuito de agradar e lisonjear.

humana.

${ }^{5}$ C. Ampolo 1993: X-XI.

${ }^{6}$ É o que Plutarco nos diz, por exemplo, na Vida de Péricles, 13. 14-16, sobre duas vítimas desse processo: Fídias e o próprio Péricles. 
A aproximação de Teseu a Rómulo justifica-se, antes de qualquer outro motivo, pelo facto de ambas as figuras estarem associadas aos primórdios da duas cidades que se equivalem - Atenas e Roma.

Teseu é, primeiramente, designado como oikistes, fundador, e Rómulo por pater, designação que traduz uma relação visceral, bem mais profunda que aquele termo, com a cidade fundada. ${ }^{7}$

Para fazer vénia à tradição de um Teseu oikistes de Atenas, Plutarco utilizou tal recurso, introduzindo uma diferença de grau no papel de fundador, e assim preparar o terreno para realçar a distância entre a actuação do filho de Egeu e a do de Rea Sílvia através dos verbos utilizados. Teseu 'congregou' (synoikise) Atenas, enquanto Rómulo fundou, 'construiu' (ektise) Roma. ${ }^{8}$

O verbo ktizo traduz uma acção de alcance bem mais profundo que a primeira, é criação a partir do nada, lançar de fundamentos. Implica, também, uma concepção prévia de conjunto e a sua realização, com uma solidez que é garantia de estabilidade e perdurabilidade; synoikizo por seu turno, supóe reconversão, abandono do espaço ou hábitos de origem e criação de um espaço e normas comuns - Teseu terá que destruir primeiro os pritaneus locais para poder impor um pritaneu comum. ${ }^{?}$

A eficácia do seu empreendimento decorrerá, assim, da capacidade humana de fazer perdurar um pro-
7 Thes. 1. 5 .
${ }^{8}$ Ibid. 2. 2.
${ }^{9}$ Ibid. 24. 3. 
jecto, mediante o exercício continuado de um sábio equilíbrio - o que pede a intervenção decidida de um governante e a inequívoca visibilidade, na sua pessoa, dos padróes ético-políticos que pretende impor. $\mathrm{Na}$ synkrisis das biografias de ambas as figuras, Plutarco decidir-se-á, definitivamente, pela supremacia de Rómulo, que prepara desde esta primeira etapa.

A diferença entre a acção fundadora de Rómulo e a de Teseu traduzir-se-á, acaso, numa diferença de raiz entre a estabilidade da aniketos Rhome $e^{10}$ e a aventura da contingência que a democracia ateniense conheceu? Denunciará o perfil de cada uma das figuras a natureza e o modo de ser da obra executada por cada uma delas? Assim sendo, em cada uma se configuram, num processo de dimensão quase simbólica, os determinantes ético-políticos que caracterizam e diferenciam as cidades de que foram fundadores.

Ocupar-me-ei, especificamente, destas dimensôes no Teseu de Plutarco. Isto leva-me, necessariamente, a considerar o modo como Plutarco utilizou os dados da tradição sobre o fundador de Atenas, em correlação com a sua perspectiva sobre os fundamentos e qualidades da obra criada - o sinecismo e a democracia ateniense. Para tal, onde o rigor das fontes históricas falha utiliza o polígrafo de Queroneia a "memória cultural”, devidamente submetida ao filtro da racionalização, de modo a dar consistência à vida de Teseu. ${ }^{11}$

Quanto à sua origem, o mais provável é Teseu ter sido, primordialmente, um herói local do espaço rural

${ }^{10}$ Ibid. 1. 5.

${ }^{11}$ C. Ampolo 2002: 281 ss. 
do nordeste da Ática. ${ }^{12}$ Maratona e Afidnas constituem, de facto, o cenário onde se desenrolam alguns dos episódios mais antigos do mito, como a luta contra o touro, ou o ocultamento de Helena, raptada ainda criança. Da ligaçáo de Teseu a Maratona constitui ainda eco a decoração da Stoa poikile em Atenas, consoante a descreve Pausânias, 1. 15. 3. Aí se encontrava representado o herói, saindo da terra para combater os Persas em Maratona. A cena é paralela à que descreve Heródoto a propósito da tentativa persa de tomar os tesouros do santuário de Delfos. ${ }^{13}$

O nascimento mítico de Teseu em Trezena poderá, então, corresponder a uma fase posterior de expansão do conhecimento e acolhimento do herói, se tivermos em conta que, anteriormente à fixação dos Dórios na região parecem ter aí residido Iónios — naturalmente vindos do norte.

Foram descobertas em Olímpia várias trípodes de bronze, provavelmente do séc. VIII a. C., em que se pode ver representado o Minotauro. ${ }^{14}$ Todavia, a mais antiga representação da luta entre o herói e o monstro de Creta pode ser observada numa ânfora cicládica datada da primeira metade do séc. VII a. C., que se encontra no museu de Basileia.

De qualquer modo, da expansão da aceitação do herói por espaço helénico decorre uma singular genealogia e origem geográfica de carácter mítico - aquele

${ }^{12}$ H. Herther 1936: 177-239, apoiado por H. J. Walker 1995: 9 ss.

${ }^{13}$ Heródoto, 8. 38-39.

${ }^{14}$ Vide H. J. Walker 1995: 16. 
que se virá a converter no herói tutelar de Atenas por excelência, no criador do sinecismo e na figura em que se vão projectando os próprios valores de uma Atenas idealizada, é filho da união entre Egeu, o descendente da autoctonia ática, e uma mulher da casa de Pélops dórica, pois, por excelência. ${ }^{15}$ União que Plutarco explica por ter sido consumada pelo engano (hapate) ou pelo acaso de um oráculo mal compreendido. ${ }^{16}$

Trata-se, como já tive oportunidade de sublinhar, ${ }^{17}$ de uma origem 'descentrada' em relação a Atenas do herói ateniense. Ele terá que percorrer o caminho de Trezena até Atenas, até ao reconhecimento paterno e à adopção pela cidade. Defrontrará, nesse caminho, aventuras e perigos, decalcados sobre os de Héracles, conforme Plutarco reconhece.

Esse 'descentramento' afecta as próprias referências identitárias de Teseu. Teseu foi criado em segredo, segundo Plutarco, com uma falsa referência paterna a de Poséidon - para ser confrontado, no despontar da sua virilidade, com a sua verdadeira origem - a de filho de um pai humano —, através dos sinais de reconhecimento ocultos pelo rochedo que conseguiu remover. O jovem conhece, finalmente, a sua real ascendência, mas ambas as referências pesam, numa espécie

${ }^{15}$ H.J. Walker 2002, cap.2, mostra como o perfil da figura sofre, mesmo no séc. V, oscilaçóes que são fruto da projecção de concepçóes de governo e papel do governante na época, da política expansionista de Atenas no tempo de Címon, ou do questionamento das estruturas políticas da Cidade e da sua eficácia.

${ }^{16}$ Thes. 3. 5.

${ }^{17}$ M.C.Fialho 2002: 71-72. 
de paternidade dupla ou ambígua, mesmo por detrás da versáo racionalizada de Plutarco, ${ }^{18}$ quando aquele adopta, para a afirmação da sua imagem, um critério de exigência de comportamento e de excelência, imposto simultaneamente pelo facto de ser publicamente considerado como filho de um deus e pelo modo como se quer vir a apresentar perante o seu verdadeiro pai. ${ }^{19}$

O jovem escolhe o caminho para Atenas por terra e não por mar, por ser o mais difícil e por poder aí evidenciar a sua coragem. Pensa, assim, determinar o efeito do seu aparecimento público na cidade, deixando, atrás de si, um rasto de vitórias sobre perigos e ameaças.

Nota Ampolo ${ }^{20}$ que a multiplicidade de aspectos da figura de Teseu deu azo a explicaçóes diversas sobre a sua verdadeira dimensão original: entre outras a de réplica de Héracles, de herói iónico, de herói iniciático de ritos de passagem da efebia à maturidade — de que seria eco o episódio da aventura em Creta e do resgate.

Teseu em Plutarco parece-me concentrar simultaneamente traços que atestam a aglutinação de leituras e projecçóes diversas na figura, conferindo-lhe uma complexidade e contradiçóes que se tornam inalienáveis do perfil com que nos surge. Se a expedição a Creta

${ }^{18}$ Op. cit. cap. 3. Em Baquílides, nota o autor, Teseu é filho de Poséidon. Mas dessa filiação há ainda vestígios, mesmo em contextos posteriores, como no Hipólito de Eurípides. Só assim faz sentido o motivo dos três desejos cuja satisfaçáo Poséidon proporciona a Teseu.

19 Thes. 7. 2. A que se junta, ainda, a emulação com o exemplo de Héracles.

${ }^{20}$ 1993: xxvi-xxvii. 
pode, de facto, ser projecção de um ritual iniciático, centrífugo, a partir de Atenas, para depois à cidade regressar, na plena afirmação e pujança dos jovens, não me parece que o seja menos o caminho de Trezena até Atenas, do espaço da infância e da esfera materna até à presença paterna e ao reconhecimento. ${ }^{21}$ Percorre e completa esse caminho sem um nome assumido, como Plutarco assinala. Nesse caminho várias provas se póem ao jovem, que com elas se confronta e as vence, aproximando-se dos gestos de Héracles, a quem imita por adesão ao seu paradigma, para, finalmente, ostentar perante Egeu, num acto público - o banquete - a arma paterna, sinal que o levará a ser reconhecido, sem que ele necessite dar-se a conhecer.

Dos pontos de contacto entre os feitos de Héracles e os de Teseu, e da afinidade entre estas duas figuras, extrai Plutarco uma expressiva motivaçáo para a escolha do itinerário do filho de Egeu — o seu caminho para Atenas através da Megárida e não por mar.

Sobre a educação de Teseu, pouco nos diz Plutarco. Esteve aos cuidados do avô paterno, Piteu, sophotatos, mas detentor de uma sabedoria prática que, certamente, não é alheia ao engenho com que persuadiu Egeu a aproximar-se de Etra, e que teria transmitido ao neto como metis, demonstrada nos feitos em Creta e mais própria do protótipo do herói iónico. Do preceptor de Teseu, Cónidas, apenas ocorre o nome ${ }^{22}$ - não se menciona a estratégia ou a eficácia pedagógica -, talvez

${ }^{21}$ M.C.Fialho 2002: 72-73.

${ }^{22}$ Thes. 4. 
para sublinhar a influência de Piteu . Plutarco enfatiza um outro aspecto, determinante na formação de Teseu — o da força do exemplo paradigmático da acção de Héracles, transmitido em relatos que lhe suscitaram uma admiração inflamada. É esta a motivação para a escolha do caminho até Atenas: ${ }^{23}$

Do mesmo modo a admiração pelo valor de Héracles levava Teseu a sonhar de noite com os seus feitos e de dia, dominado e exaltado pelo desejo de emulaçáo (zelos), pensava em praticar feitos semelhantes.

A aproximação de Teseu à figura de Héracles é modelada pelo erudito de Queroneia à luz das suas convicçôes acerca do papel educativo do exemplo das acçôes ilustres, operado sobre a alma humana, e a que alude com frequência nos seus escritos de filosofia moral.

Plutarco, ao sublinhar a força educativa do exemplo de Héracles com o caso prático do jovem Teseu, chama, por sua vez, a atenção para o potencial educativo e formativo das próprias Biografias que escreve. Ao exemplo como factor dinâmico da paideia dedica o escritor um dos mais belos e expressivos passos das Vitae - a abertura da biografia de Péricles - recorrendo a uma comparação muito do seu gusto, a do efeito de estímulos visuais sobre a própria visão: ${ }^{24}$

Pois tal como a cor mais benéfica para os olhos é aquela cujo brilho e doçura estimulam e tonificam a visão, assim

${ }^{23}$ Thes. 6. 9.

${ }^{24}$ 1. 3-4. 
mesmo se torna necessário encaminhar o pensamento para a contemplação de espectáculos que, por efeito do prazer que suscitam, conduzem aquele ao bem que lhe é intrínseco.

Tais espectáculos consistem nas acçóes nascidas da virtude e despertam, nos homens que os observam, um sentimento de emulação e o desejo de os imitar.

Convertidas platonicamente num equivalente ao bem, que se impóe, pela sua beleza, e fascina a alma humana a contemplá-lo, tornando-se, assim, motor da acção humana, as obras nascidas da arete actuam, suscitando em quem delas toma conhecimento, um natural anseio de imitação (mimesis) através do sentimento de emulação e desejo de as igualar (zelos kai prothymia). ${ }^{25}$

Na mesma Vita, em 2. 1-2, Plutarco acrescenta:

Não acontece necessariamente, se uma obra nos encanta pela sua beleza, que o seu autor seja digno de admiração. Por isso, não há vantagem em contemplar tais obras que não provocam a emulação nem o arrebatamento que suscita o desejo e o afá de as imitar. A virtude, em contrapartida, pelas acçóes que inspira, dispóe claramente à admiração pelos feitos e à simultânea emulação com os seus autores.

Identificam-se, nestas palavras, ecos da velha questão platónica da República: a beleza das obras de arte, em si, pode encantar e envolver os sentidos, mas tal

${ }^{25}$ Quanto ao papel da emulação (zelos) como um dos componentes essenciais na formação moral das figuras das Vitae de Plutarco, e sobre o lugar que ocupa a referência a zelos nprogressáo peculiar do esquema das biografias, vide A. Pérez Jiménez 1985: 100-105. 
envolvimento não acarreta consigo elevação da alma essa só é motivada por obras que apelem para o aperfeiçoamento ético através de uma emulação suscitada pelo apelo e força de um paradigm. É o apelo à identificação, suscitado pela beleza da própria virtude, que tem validade ética e capacidade de orientar uma paideia eficaz. Para o polígrafo de Queroneia essa atracção das obras da arete exercida sobre a alma em formação pressupóe nesta última uma predisposição que é também arete inata e que aspira, ao receber o estímulo de uma acção modelar que se impóe como espectáculo, a elevar-se à superioridade desta e com esta se medir, numa saudável emulação, traduzida em actos.

Ora os perigos que Teseu defrontou no percurso até Atenas, os malfeitores punidos e exterminados traduzem o efeito actuante do exemplo pedagógico de Héracles sobre um jovem cuja predisposição para a philantropia e para a megalophrosyne se realiza em actos que têm como objectivo exercer e manifestar a coragem e libertar aos viandantes os caminhos. Essa série de aventuras aparece, assim, no relato de Plutarco, integrada no todo de um percurso conseguido, coeso, sem dispersão, até à figura paterna. Nota Ampolo o cuidado posto por Plutarco no relato da juventude dos biografados, para aí apontar o potencial de características que se hão-de tornar dominantes nas suas existências. ${ }^{26}$ Todavia, nesses mesmos feitos se denuncia já, discretamente, num relato de estupro diluído - o de Periguna - a presença de

${ }^{26}$ 2002: 282-285. 
impulsos que Teseu não controlará. A força do impulso erótico e do irresistível desejo de saciar o prazer hão-de tomar, progressivamente, conta da conduta de Teseu até lhe desestruturar os seus projectos de acção política, causando a sua ruína. Reconheçamos que esse elemento está também presente no mito de Héracles e foi causa, para este, de fatais dissabores.

Pode, antecipadamente, concluir-se que Teseu não soube apropriar-se criticamente do paradigma pedagógico que tanto o fascinou e de que se quis aproximar. Estaria, no espírito de Plutarco, presente a ideia de fazer perceber ao seu leitor a necessidade de apropriação crítica dos exemplos das Vitae? De que com os excessos dos heróis, ainda que corajosos e nobres, se aprende também, pela negativa? É bem provável que sim.

Ainda assim, cultivando a força do exemplo, Teseu, num impulso de generosidade, oferece-se para integrar o grupo de reféns destinado a Minos. O que suscita, por seu turno, a admiração dos atenienses pela sua grandeza de espírito (phronema) e pela sua devoção ao povo (demotikon): ${ }^{27}$

Estas queixas afligiam Teseu, que entendeu ser justo não se alhear, mas antes tomar parte na sorte dos seus concidadãos, pelo que se foi oferecer espontaneamente, antes do sorteio. Aos demais pareeu admirável esta grandeza de espírito e louvaram a sua devoçáo ao povo...

Todavia, ao oikistes fundador de ritos, libertador de caminhos e da juventude ateniense, falta a capacidade

${ }^{27} 17.2$. 
de exercício — askesis — da razão sobre a parte irracional da alma. ${ }^{28}$ Mesmo na grandeza de espírito que o leva a arrostar com o perigo percebe-se o componente impulsivo que o força a ceder a um prazer sob a forma de eros descontrolado - o que se converterá na causa da sua ruína. Como foi dito, já nessa espécie de caminho iniciático de Trezena até Atenas se denuncia tal fraqueza. Plutarco assinala em mais de uma dezena as mulheres tomadas à força ou seduzidas e abandonadas por Teseu até ao clímax da sua hybris de hedone, atingido com o rapto de Helena ainda criança: ${ }^{29}$

Este comportamento faz suspeitar que ele agia por violência e por prazer .

Quer isto dizer que, para o caso de Teseu, as qualidades promissoras reveladas na juventude vão entrar em tensão progressiva com a força da paixão, que ele não há-de ser capaz de dominar. Por essa via será vítima da sua própria desordem de alma e porá em risco a boa ordem da cidade que governa. Não é a generosidade, filha de um impulso, que deve guiar a acção de quem governa, mas a devoção ao bem comum. Mesmo que o impulso tenha como consequência, uma vez, a libertação de alguém (os jovens enviados para Creta), enquanto impulso, ainda que generoso, não deixa de representar uma forma de prisão do homem a forças

${ }^{28}$ Sobre a askesis como uma das principais condiçóes para alcançar a virtude, veja-se A. Pérez Jiménez 1985: 35 ss.

${ }^{29}$ Rom. 35. 2. 
irracionais, do mesmo modo que eros. No primeiro caso trata-se de uma forma de philautia com repercussóes benéficas. No segundo caso, a philautia terá consequências desastrosas. É frágil a fronteira entre auto-estima e egoismo quando o homem não alcança a consistência ética dada por uma paideia a que não é alheio o esforço, o olhar crítico sobre os paradigmas que se oferecem e a vigilância sobre si mesmo.

Se, para Plutarco, os males humanos não podem, frequentemente, ser imputáveis aos deuses, mas ao acaso e à acção humana que, combinada com a tyche, pode levar o homem ao sofrimento, ${ }^{30}$ o filósofo entendia, certamente, o destino de Teseu como ilustração deste princípio - conforme o atesta a própria synkrisis. ${ }^{31}$ Ele náo deixa de ver no rapto de Helena - o maior dos desmandos cometidos por Teseu - uma das causas do malestar e da sedição (stasis) do povo ateniense contra o seu governante. ${ }^{32}$

O criador do sinecismo não soube, por uma falha estrutural do seu carácter, conferir estabilidade e solidez a um vínculo social que é a base da estrutura de uma comunidade organizada - a uniáo conjugal. Rómulo, fundador e construtor de Roma, usou-a, em contrapartida, como pedra angular da sociedade romana e como um dos pilares da conciliaçáo e aliança política que fortalece o estado e que deu azo à prosperidade de Roma. ${ }^{33}$

${ }^{30}$ Vide A. Pérez Jiménez 1973: 101-110.

${ }^{31}$ Rom. 32. 1.

${ }^{32}$ Thes. 31 ss.

${ }^{33}$ Rom. 35. 2-3. Para uma melhor compreensão da importância do texto no contexto da synkrisis da bigrafia de Teseu e de Rómulo, 
Mais ainda: como homem de acção impulsiva, o criador do sinecismo não soube desenvolver, pelo exercício e pela pertinácia, as qualidades racionais do bom governante, mesmo como mero guardiāo das leis, de modo a poder dar coesão à nova configuração da Cidade. O prazer, sob a forma de eros, agiu como factor de dispersão e força centrífuga que o desenraizou de Atenas. Prometendo à cidade a isoimoiria, divide-a, na prática, em classes sem direitos equivalentes, ${ }^{34}$ prometendo-lhe uma democracia de que ele seria mero chefe na guerra e guardiāo das leis (24. 2), afasta-se da cidade e deixa que o povo singre sem timoneiro, ao sabor de demagogos e dos seus próprios vícios latentes, deixa que as várias classes se digladiem entre si. ${ }^{35}$ Após ter dado livre curso às paixóes, numa alma desordenada, que encontra Teseu, de regresso à cidade? ${ }^{36}$

Quando quis tomar de novo conta do poder, como anteriormente, e assumir a chefia do governo, caiu no meio de revoltas e desordens. Descobriu que quantos o odiavam antes de partir tinham acrescentado ao ódio o facto de já não terem medo dele.

Deixando, certamente, passar ecos da concepção platónica de uma República que tem em si a imagem da própria alma, Plutarco sublinha a similaridade do percurso de Atenas, progressivamente tomada pela paixão do mando e pela desordem, com o do seu fundador.

em que se situa, veja-se H. Erbse 1956: 398-424.

${ }^{34} 25.1-2$.

3532.1 ss.

3635.4 . 
O papel do governante ideal, para Plutarco, identificado com o do monarca que age com a mesma intervenção ordenadora com que a razão opera na alma, está longe desta figura excepcional, mas marcada por contradiçóes, por falhas estruturais que determinarão o seu exílio e a sua morte, despenhando-se do alto de um rochedo.

A sua morte pode ser tida como a paradigmática imagem do desenlace do percurso existencial daquele que ao mais alto subiu para se despenhar no abismo perspectiva antropológica táo cara à poesia grega arcaica, à tragédia clássica, às Histórias de Heródoto. Quer isto dizer que Plutarco, apesar de desprezar os relatos dos poetas, póe-nos perante um itinerário quase trágico de uma figura heróica, com a diferença de faltar à figura do fundador de Atenas o necessário reconhecimento do limite e do erro, característico dos protagonistas trágicos.

Em conclusão, parece haver, entre as virtudes e fraquezas de Teseu e as virtudes e fraquezas da sua própria cidade, uma estreita simbiose, uma correspondência que Plutarco teria esboçado conscientemente, de modo a que os vícios e a magnitude do criador do sinecismo assumam uma dimensão arcaica, no sentido etimológico do termo. Na praxis de Teseu transparece, em meu entender, a etiologia das próprias fissuras e contradiçôes da democracia ateniense e no destino daquele pode ler-se a antecipação do destino de uma cidade que conheceu um excepcional esplendor político e cultural, marcado pela 
philantropia e megalophrosyne, mas sem a askesis que lhe permitisse refrear a cupidez de poder e lucro.

É que essa askesis opera através da intervenção sábia e decidida do governante, num sistema de monarquia - governante atento ao seu próprio equilíbrio moral como fonte de competência para salvaguardar a harmonia do estado que governa. ${ }^{37}$

Difícil é esse equilíbrio, solicitando atenção constante, e esbatida a fronteira que o separa da degenerescência em democracia ou em tirania. Ambas são, para Plutarco, formas de governo adulteradas, de sinal contrário, mas nascidas da mesma fonte - a perda da justa relação do governante com o poder que exerce, decorrente ou da philantropia ou da philantia $^{38}$ e que o irá converter em demagogo ou em déspota. Assim o salienta na synkrisis: ${ }^{39}$

Pese embora terem nascido ambos com vocação para governar, nenhum deles soube conservar a conduta política de um rei. Dela se afastaram, porquanto um a converteu em democracia e o outro em tirania, vindo a cair no mesmo erro por sentimentos contrários. É que um governante deve salvaguardar, antes de tudo, a própria governação. E salvaguarda-a tanto quando se abstém do que lhe não convém

${ }^{37}$ A. Pérez Jiménez 2004: 49-64 formula a hipótese, com exemplos ilustrativos, de as Vitae e a respectiva synkrisis final, incluindo a de Teseu e de Rómulo, fornecerem deliberadamente modelos de leitura, de aplicação tácita, para a história de Roma do séc. I p. C. (2004)

${ }^{38}$ Rom. 31.

39 Sobre a função da synkrisis nas Biografias vide Pelling (1986) 83 ss. , Th.Duff 1999, caps. 8-9. 
como quando procura o que lhe é conveniente. Mas aquele que afrouxa ou endurece a sua autoridade deixa de ser um rei e um dirigente para se converter num demagogo ou num déspota que inspira ódio ou desprezo nos homens a quem governa. O primeiro dos vícios em causa parece decorrer da brandura e da humanidade, o segundo do egoismo e da dureza.

Podemos, assim, dizer que o papel da philautia como limitação crescente e não ultrapassada em relação às qualidades morais de philantropia e megalophrosyne de Teseu é retomado na synkrisis final de modo a revelar-se como uma tensão que afecta a própria governação e que se contagia à cidade. Talvez Plutarco pretenda assinalar que o destino da poderosa democracia de uma Atenas que foi um centro de cultura e pensamento fulgurantes se deveu à philautia do seu poder hegemónico e da luta pela preponderância no interior da cidade: como atrás disse, entre auto-estima e egoismo, mesmo falando de uma comunidade, caso a solidez de uma formação ético-política esteja ausente, a fronteira é débil. 


\section{Sócrates e a Paideia Falhada de Alcibíades}

Maria do Céu Fialho

Em muitas das Vitae de Plutarco apercebemo-nos de uma espécie de tensão agonística entre valores naturais, que se deixam adivinhar nas potencialidades que o seu carácter parece revelar à partida, e estímulos externos ou contingências que, muitas vezes, póem à prova e se sobrepóem a essa natureza promissora. Do resultado dessa luta, seja ele já perceptível na juventude, ou na maturidade ou no fim da vida, decorre a configuraçáo final do ethos do herói.

Podemos, entre outros, dar o exemplo de Alcibíades jovem, em quem o próprio Sócrates vislumbrou, mais além da sua beleza externa, marcas de euphyia e arete que era necessário ajudar a desenvolver pela filosofia $(A l c .4 .1.) .{ }^{1}$ Teseu, por sua vez, enquadra-se naquele tipo de heróis que, a partir de uma juventude promissora, guiada pelo exemplum interiorizado de Héracles que representou para ele um factor de auto-educaçáo e determinação de comportamento, se veio a perder na maturidade. A coragem e philanthropia de Teseu perderam coerência e deixaram de dar consistência ao seu ethos no momento em que o fundador de Atenas cedeu a uma forma de philautia decorrente do desejo de satisfazer os seus próprios impulsos. Como terceiro exem-

${ }^{1}$ Sobre a importância da Filosofia no desabrochar das virtudes e no caminho para uma eudaimonia mais qualitativa da alma em Plutarco vide F. Becchi 1999: 25-43. 
plo, recorde-se Demétrio (52) que, como prisioneiro de Seleuco, se entregou, nos últimos anos da sua vida, ao império do vinho e da comida, uma vez que não lhe restava esperança de recuperar a liberdade.

Assim, valores e contra-valores, vícios e virtudes se vão manifestando em acto até ao apuramento final do que vale o exemplo pedagógico de uma biografia. Esta definição dinâmica de carácter através das acções é de raiz aristotélica ${ }^{2}$ - reconhece-se toda a filosofia de acção analisada em Ética a Nicómaco. Por sua vez, a força de uma arete inata, que representa a superioridade platónica da alma sobre o corpo, está presente no reconhecimento que Plutarco faz da existência de um potencial de qualidades morais, reveladas à partida, num ser ainda jovem. Elas são reforçadas pela educação, que o preparam para defrontar agentes externos, como a tyche e os seus caprichos ou a pressão do contexto social. É nesse confronto que aquilo que podemos designar como o "carácter estruturado" se define, de acordo com a força moral do herói. É nesse confronto que Plutarco conduz o leitor a avaliar o quanto pode a força da educaçáo (se acaso reforça uma boa physis) ou o quanto pode a força da Fortuna, seja ela cruel, instável, ou demasiado próspera.

Neste contexto revela-se particularmente interessante o caso da vida de Alcibíades. Sobre esta fascinante e polémica figura afirma Plutarco (4.1-2) — curiosamente no mesmo capítulo inicial em que refere, de forma enfática, a força positiva da presença de Sócrates:

${ }^{2}$ A. Pérez Jiménez 1973: 103 ss. 
Já muitos homens de origem nobre vinham rodeando Alcibíades e cortejavam-no, mas enquanto se tornava evidente que os outros se sentiam atingidos e atraídos pelo esplendor da sua juventude, o amor que Sócrates lhe devotava constituía um testemunho irrefutável da natural disposição do jovem para a virtude. Aquele, ao notar que os dons inatos do jovem se manifestavam e transpareciam no seu aspecto exterior, teve receio que a riqueza, a condição social, a multidão de cidadãos, de estrangeiros e de aliados o estragasse pela adulação e com favores. E então protegia-o, em atitude vigilante, como se ele fosse uma planta em flor, de que se cuida para não deixar que perca o fruto ou que seque. De facto, não há pessoa alguma a quem a fortuna (tyche) tivesse de tal modo rodeado e cumulado dos chamados bens, exteriores, a ponto de se tornar invulnerável em relação à filosofia e insensível a palavras francas e mordazes.

E é na Vita de Alcibíades que irei centrar este estudo. O passo citado pertence ao conjunto de capítulos iniciais que se ocupam, de modo aparentemente desordenado, da ascendência e de episódios da infância e adolescência desta figura. Não encontramos nesta biografia propriamente um prólogo. ${ }^{3}$ Plutarco entra directamente no assunto: Alcibíades descende de heróis da saga épica, ao mesmo tempo que a linha materna o liga aos Alcmeónidas. Seu pai combateu os Persas em Artemísio e os Beócios em Coroneia, onde morreu. Péricles e Arífron foram seus tutores, teve uma mulher da Lacónia como ama e como pedagogo um homem chamado Zópiro.

${ }^{3}$ Ph. Stadter 1988: 275-295 distingue dois tipos de prólogo e inclui este no grupo dos "proémios integrados". 
Plutarco antecipa aqui, como uma espécie de determinante da futura sorte de Alcibíades, o papel da presença de Sócrates na sua vida: foi a eunoia e a philanthropia do filósofo que contribuiram substancialmente para a doxa de que o jovem viria a gozar (1.3.).

Da sua beleza física imperecível, que o acompanhou até à morte, Plutarco passa para a referência às inconsistências de carácter reveladas na idade adulta e que relaciona com pragmasi megalois kai tychais polytropois (2.1.). O autor sublinha, nestas consideraçôes prolépticas, como se viria a reconhecer em Alcibíades um philoneikos e philoprotos, para regressar à sua infância e juventude e ilustrar, com breves anedotas, o carácter que já se anunciava. A sua rebeldia para com os mestres denuncia até que ponto este jovem promissor é avesso à influência da educação e sabe desde cedo, por intuição, jogar com as circunstâncias e manipular, servindo-se dos seus dotes. No entanto, esta ordenação aparentemente caótica dos capítulos iniciais da vida de Alcibíades contém uma semiótica própria. ${ }^{4}$ Plutarco joga com uma espécie de prefiguração do que será a própria anarquia da vida do biografado, embora os episódios relatados corroborem a sua extrema incrível capacidade de resposta rápida às situaçóes e o seu arrojo. Uma leitura mais superficial deixaria o leitor criar expectativas de estar perante um indivíduo genial - que o era - de quem se poderia vir a esperar um brilhante futuro.

${ }^{4}$ Demonstra-o Th. Duff 2003: 94 ss. 
Do mesmo modo, o fim da vida de Alcibíades condensa, numa espécie de simbologia, a síntese da sua própria existência: é um fim envolto em incerteza, polémico, escandaloso e ambíguo pela própria cosmética feminina com que aparece no seu sonho premonitório e pelas vestes de cortesã com que, por fim, Timandra o cobre. $^{5}$

A ambiguidade remete para o episódio de juventude de luta livre com o adversário, que o acusa de recorrer a processos pouco ortodoxos (2.2.): ${ }^{6}$

Tu mordes, ó Alcibíades, tal como o fazem as mulheres!

O processo de condensação simbólica constitui um recurso de escrita do gosto de Plutarco, para tornar mais forte o poder de sugestáo do quadro final sobre o percurso que a ele leva. Outros desfechos de biografias o ilustram, como, por exemplo, o da de Teseu, de Cato Minor ou de César. Esta última envolve na narrativa o fim do assassinado, do assassino e da república romana. Diga-se, de passagem, que se trata de um recurso próprio da narrativa poética e que provoca, por parte do leitor, uma adesão ao texto que está para além da razão e que se prende com os efeitos de sugestão e representação próprios da poiesis.

${ }^{5}$ Sobre o significado dos sonhos nas Vidas de Plutarco vide F. E. Brenk 1975: 336-349.

${ }^{6}$ Th. Duff 2003: 96 sublinha o modo como este episódio, entre outros, funciona como uma prefiguração da ambiguidade sexual do biografado. Esta atingirá o seu ponto culminante no final da Vida. 
As relaçôes de sangue de Alcibíades ligam-no aos Alcmeónidas, simultaneamente ilustres e ligados a um caso passado de sacrilégio. A coragem do pai parece ser espelho dos futuros feitos militares do filho. Não deixa de ser expressivo, no discurso de Plutarco, dar aquele como combatente contra Persas e contra Gregos, assim como anotar o papel de tutor de Péricles, cuja influência e exemplo parece nada ter significado para o jovem, em simultâneo com um pormenor aparentemente insignificante: o da ama, oriunda de um espaço ligado a Esparta.

Por outro lado, o registo da beleza física antecede consideraçôes sobre o ethos de alguém que parece preso não só das alteraçóes da fortuna, mas da sua própria beleza que o condiciona a ser admirado e assediado sem ter estrutura ética para resistir à pressão desse assédio. Alcibíades apresenta-se, à partida, condicionado por essa beleza, pelo arrojo demonstrado, por um carácter fraco e volúvel e por uma inteligência brilhante a desempenhar um agitado protagonismo na vida de Atenas. Frequentemente utiliza Plutarco a conjugação tolma kai synesis para definir essses actos de arrojo que vão da infância ao fim da vida. Não é andreia o termo escolhido - mas este é o termo que Plutarco selecciona, em contrapartida, para designar a coragem de Coriolano e sublinha, na biografia correspondente, que este termo equivale ao que os Romanos designam por arete. Isto é, adivinhamos no grego do autor, o esforço de equiparação ao latim uirtus. Com ela se conjugam a temperança e o sentido de justiça 
(enkrateia kai dikaiosyne). O lado negativo do seu carácter reside na extrema arrogância e orgulho que o hão-de perder.

O começo da biografia de Coriolano prepara já a synkrisis entre as duas Vitae, na medida em que responde, de alguma forma, ao paralelismo entre a infância das duas personagens. Coriolano também ficou órfão de pai na infância, mas manteve sempre, em relação à mãe, um grande afecto. Em Alcibiades não se fala, à partida, de afectos, mas de grupos de jovens que rodeavam o protagonista e o seguiam. A Coriolano faltou-lhe a presença vigorosa de um pai e a educação que desenvolvesse as virtudes do seu carácter e inteligência, refreando os defeitos e impulsos, como a cólera, a que era propenso, e a arrogância. Com a bela imagem de matriz platónica ${ }^{7}$ realça Plutarco o papel necessário que a educação exerce sobre as naturezas nobres e os caracteres potencialmente bons (Cor.1.3):

O mesmo Márcio, por outro lado, confirmou a razão de quantos pensam que uma natureza nobre e generosa, se lhe falta a disciplina, é capaz de produzir, juntamente com os bons frutos, outros que não têm qualidade, como acontece em relação a um solo fértil que não tenha sido objecto dos cuidados do agricultor.

Estas consideraçóes constituem uma espécie de resposta ao itinerário de juventude de Alcibíades. Este, em contrapartida, teve tutores de prestígio, teve quem

${ }^{7}$ Cf. Platão, Rep. 491, d-e. 
se ocupasse da sua educação e, sobretudo, contou com a dedicação de Sócrates, empenhado em fazer desabrochar o que de melhor havia no jovem. O que, à partida, se pode considerar o ethos potencial de Alcibíades, com as boas e más qualidades que exigiam a intervenção de um educador, mas também o esforço do próprio, foi sendo sujeito a agentes externos contraditórios, de modo a que o de que pior havia em Alcibíades prevaleceu, como resposta a um destes tipos de agentes.

Por um lado, consideremos o conjunto daqueles que admiravam o corpo e manifestaçóes físicas de Alcibíades - os aduladores, os jovens movidos pelo impulso de um eros físico, que nele exacerbavam o desejo de satisfazer o prazer imediato. A este estímulo facilmente se associa o prazer do vinho e a embriaguez, a imoderação nos banquetes e na vida pública, a procura da glória fácil, ainda que com o sacrifício da coerência, da correcção ética, do bem da cidade. O episódio relatado por Plutarco em 4.5 serve como de pórtico a um historial de atitudes de insolência e prepotência de Alcibíades, manifestadas no espaço de convívio social, como é o do banquete, provocadas pela imoderação na bebida e pela consciência de que as pessoas que humilha estão sob o império do fascínio que ele exerce, como é o caso de Ânito: ${ }^{8}$

Acontece que este homem, que estava apaixonado por Alcibíades, ao convidar alguns convivas para a ceia o convidou também a ele.. Alcibíades declinou o convite, mas depois

${ }^{8}$ Sobre este assunto veja-se M. C. Magán 1999: 171-180. 
de ter bebido em excesso em sua própria casa, juntamente com alguns amigos, fez-se, com tal comitiva, ao caminho até casa de Ânito. Postou-se na soleira da sala de banquete deste homem e, ao ver as mesas cobertas de taças de prata e ouro, deu ordem aos escravos para se apossarem de metade e a levarem para sua casa. E nem sequer se dignou entrar. Depois de ter cometido esta desfaçatez, foi-se embora. Os convivas ficaram indignados e disseram que Alcibíades se tinha comportado com Ânito de modo grosseiro e sumamente insolente (bybristikos kai hyperephanos).

Esta intervenção de Alcibíades a meio do banquete do antagonista de Sócrates recorda um outro Banquete, o de Platão, onde a problemática de eros é discutida e em que Alcibíades, chegando também com atraso, manifesta não estar apto a passar além do plano da erótica do mundo sensível.

A corrupção de Alcibíades arrasta a corrupção de companheiros da sua geração. E se as adversidades da tyche podem funcionar como uma espécie de teste de carácter, enfraquecê-lo mas também fortificá-lo, no caso de Alcibíades o factor tyche, como se viu no passo acima citado (4.2), por lhe ter sido excepcionalmente favorável, não o pôs à prova e arredou-o da disposição de alma para reconhecer as limitaçóes do humano e a necessidade de uma reflexão filosófica e da adesão a uma filosofia prática.

De facto, as alusôes à presença de Sócrates estão contidas nesta primeira fase da vida do jovem e aparecem intencionalmente entremeadas com os desmandos do protagonista. A referência à relação erótica física com 
Ânito, fonte de arrogância e desequilíbrio para Alcibíades (4.5), aparece antecedida da referência ao eros de Sócrates por Alcibíades, ao qual se contrapôe (4.1). É que este representa o eros direccionado para as qualidades inatas, que se dedica a ajudar a desenvolver na alma do eroumenos. Numa espécie de vivência caótica Sócrates representa a voz da Filosofia, o apelo da ordem e à ordem da alma, pela askesis de uma filosofia prática que faz desenvolver no indivíduo o amor ao Belo e ao Bom, nunca separando eticamente aquele deste. Mas Sócrates constituia uma excepção. Apenas Sócrates, pela visão privilegiada de um daimonios que depurou a capacidade de ver através do desprendimento do plano do material ao cultivar a verdadeira Filosofia como modo de vida verdadeiro, podia vislumbrar as qualidades, em estado seminal , que existiam na alma de Alcibíades e que era urgente fazer frutificar. Este constitui o segundo agente que luta por anular o primeiro de que se falou. No entanto, a estratégia das referências à acção e às intençôes de Sócrates faz perceber que a sua acção se tornará ineficaz, sobre um jovem envolvido por um turbilhão de estímulos que apelam para o que de pior há em si, reforçados por uma tyche em aparência excepcionalmente favorável, como agente externo - exothen. Assim o atesta o passo acima citado (4.1-2).

Segue-se a referência à tyche excepcional, que tornou o jovem "invulnerável em relação à filosofia”, como antecipação, à maneira da tragédia esquiliana, entremeada no discurso sobre a influência de Sócrates na sua pessoa e a atracção por Sócrates, que o levava a 
ouvi-lo com encanto, como quem ouve um amante, e a tornar-se companheiro habitual do filósofo, desprezando "amantes ricos e famosos". Terá Alcibíades sido alguma vez verdadeiramente tocado pela sabedoria socrática? A planta frágil possuia qualidades para isso, mas o campo em que nasceu (antecipando a imagem da Vita de Coriolano) e todas as condiçōes adversas ao seu crescimento tornaram vã a acção de Sócrates. É o que Plutarco pretende mostrar à partida com a organizaçáo do seu discurso. Mais tarde será mais explícito, ao referir ten tes physeos anomalian deste homem (16.6). Nem o próprio Alcibíades se apercebeu, na fase de proximidade de Sócrates, que a acção benfazeja do génio filosófico não encontrava verdadeiramente condiçóes para exercer a sua eficácia (4.3-4):

...ele chegou a pensar que a acção de Sócrates constituía, de facto, um gesto de assistência dos deuses para cuidado e salvação da juventude. Assim, desprezando-se a si mesmo e admirando o seu amigo, amando a benevolência deste, de quem respeitava a virtude, ele alcançou, sem se aperceber, uma "imagem do amor", consoante diz Platáo, "em resposta ao amor", e toda a gente ficava admirada por o ver comer com Sócrates, exercitar-se com ele na luta, e partilhar a sua tenda, enquanto se mostrava áspero e intratável com os seus outros admiradores...

Segue-se de imediato o episódio da embriaguez e excessos no banquete de Ânito.

A partir daí, o motivo da acção de Sócrates é tratado por Plutarco com uma hábil expressividade, de 
modo a deixar perceber que a influência do filósofo em Alcibíades se vai progressivamente perdendo, como se o crescimento desse rebento com potencialidades, na alma do jovem, fosse asfixiado por ervas daninhas (6.1):

Mas o amor (eros) de Sócrates, embora contasse com muitos e poderosos rivais (antagonistas), de algum modo dominava Alcibíades. É que o filósofo fazia apelo ao que de bom havia na sua natureza e as suas palavras dominavam-no, atormentavam o seu coração, até lhe provocar as lágrimas. Todavia, por vezes, o jovem deixava-se dominar pelos aduladores, que lhe ofereciam inúmeros prazeres (hedonas), escapava à alçada de Sócrates e sujeitava-se a ser perseguido como caça, por este, tal como se fosse um escravo fugitivo. E todavia só por Sócrates ele sentia medo e nutria reverência. Quanto aos restantes, desprezava-os.

Não é já a imagem do amor, segundo Platão, que Alcibíades sente que Sócrates nele consegue despertar, mas o medo e a reverência, de que tenta escapar, enquanto o filósofo tenta, já em vão, exercer o seu múnus nesta alma prestes a perder-se no turbilhão dos prazeres. A eficácia da influência de Sócrates é agora posta a par da dos aduladores, como seus rivais, não é já constante e não se impõe pela sedução natural. Expressiva é a imagem do escravo fugitivo.

O retrato de Sócrates, como um ser excepcional, assistido pelo daimon (17.4), como só o pode ser alguém que cultiva em tão alto grau a filosofia prática e a ela conduz os seus formandos, está em perfeita sintonia com a visão tida com respeito a Sócrates na época de 
Plutarco e com o próprio tratamento da figura em outras obras de Plutarco, sob influência do modelo dos diálogos platónicos. O seu De genio Socratis, em especial, é perceptível em vários passos das diferentes Vitae. ${ }^{9}$

A última tentativa de Sócrates para fazer desabrochar o sentido dos valores, em Alcibíades, é já uma tentativa de recurso extremo, na sequência da batalha de Potideia, para que o mérito que verdeiramente cabia ao próprio Socrates, mais do que a Alcibíades, fosse reconhecido a este. Comenta Plutarco (7.5):

Em rigor, a recompensa de mérito cabia a Sócrates; mas os comandantes, tendo em conta a condição social de Alcibíades, deixaram transparecer o desejo de atribuir a este a glória. Sócrates, que desejava incrementar no jovem a ambição por empresas nobres (to philotimon en tois kalois), foi o primeiro a testemunhar em seu favor e pediu que o amigo recebesse uma coroa e uma armadura completa ...

Isto é, o filósofo faz um apelo desesperado a algo que é, por vezes, em Plutarco, negativamente valorizado - a philotimia - e que constitui um traço de carácter acentuado em Alcibíades, para o direccionar para as boas acçôes e, assim, para o que é belo, sendo bom. ${ }^{10}$

${ }^{9}$ Platão e Xenofonte desempenharam um papel decisivo, entre outros autores, como Aristóteles, Demétrio de Falero, Panécio, para a configuraçáodo retrato de Sócrates e para a sua popularidade na Antiguidade tardia. Em relação ao caso específico de Plutarco, vide J. P. Hershbell 1988: 365-382.

${ }^{10}$ Acepçóes negativas de philotimia estão atestadas, por exemplo, em relação com doxomania (Plu. Sull. 7), kenodoxia (M. 57d), philoneikia (Ages. 23. 33), philarchia (M. 785 sq.). Como acepçóes 
$\mathrm{Na}$ retirada dos Gregos em Délios, a retirada de Sócrates, ainda que protegida por Alcibíades, quase assume o valor simbólico da saída do filósofo da vida deste homem.

Toda esta tensão de forças parece traduzir-se estilisticamente no jogo de palavras compostas com o radical phil-: à philanthropia de Sócrates (1.2) ficou a dever um contributo fundamental para a sua fama (doxa), mas o facto de se manifestar, desde cedo, philoneikos e philoprotos (2.1), fizeram-lhe alcançar fama fácil e protagonismo sem virtude, de modo a se tornar impenetrável à philosophia do mestre (4.2). Sócrates diagnostica nele uma philotimia que tenta encaminhar para o eticamente correcto, mas em vão o faz. Essa philotimia desenvolverse-á com a adulação, com a consciência dos seus dotes naturais, o pendor para o excesso e a prepotência, com a sua sorte favorável, a ponto de os cidadãos de boa reputação a encararem como um perigo, já que facilmente se poderia associar à tirania (16.1-2). No vulgo Alcibíades desperta sentimentos tão contraditórios quanto a sua própria natureza, já que é amado, odiado, e a sua presença desejada.

No contexto de uma Hélade em profunda crise, que se digladia e em que a sorte e o poder, na guerra, facilmente se alteram e favorecem uns ou outros, Alcibíades aprende, por essa mesma incontrolável ambição

positivas lembremos, por exemplo, contextos em que o conceito aparece associado a philodoxia (M. 39e), doxa (e. g. Cam. 31). O adjectivo philotimos com o significado de 'generoso' ocorre em Crass. 3 (philotimos peri xenous). Sobre a história do conceito e a originalidade de Plutarco no uso do termo vide F. Frazier 1988: 109-127. 
e sede de protagonismo, a mudar facilmente de lado e a facilmente persuadir os aliados de momento ou a trai-los, se oportuno, usando a sua synesis kai tolme (21.2, 35.1). Com igual facilidade assume, ou melhor, mimetiza o comportamento honesto e o desonesto, a prática do excesso e os hábitos de pompa, entre os Persas, como os costumes mais sóbrios e severos, entre Espartanos. Tudo isto em função da ambição e do proveito. Para o vulgo esta volúvel e genial adaptação às circunstâncias despertará o sonho da tirania (35.1). Para Plutarco, esta aberração monstruosa de carácter, que se vai agravando com a própria crise da Hélade, assume características comparáveis às de um animal, rastejante - o camaleão (23.3).

Assim, este homem que teve a capacidade de dividir e desestabilizar todo o Peloponeso, que anulou o esforço pacificador de Nícias, converteu-se numa espécie de corporização da própria crise, de materialização do espírito do tempo. Se a ordem da cidade algum paralelismo tem com a ordem da alma, a anomalia de uma physis que Sócrates não conseguiu modelar está em consonância com uma Atenas ao sabor de maiorias movidas pela força tiranizadora de impulsos. É esse o contexto em que se multiplicam os demagogos e os chefes sem escrúpulos, os senhores da guerra, que dela tiram proveito. Assim o frágil rebento da virtude secou, para dar lugar, cada vez mais evidente, aos movimentos do camaleão.

Imitando o ritmo da oscilação deste carácter e do seu destino, Plutarco conclui a comparação das Vitae de Alcibíades e Coriolano com um desfecho teatral: começa por estabelecer um paralelismo que aparenta ser 
favorável em aptidóes a Alcibíades sobre Coriolano para no fim, inesperadamente, operar um volte-face e concluir que a philotimia de Coriolano foi redimida pela sua sophrosyne e pelo desprendimento em relação às riquezas, enquanto Alcibíades se revelou como o homem mais destituído de escrúpulos e mais destituído de sentido moral - to kalon. A sua morte é o quadro que melhor ilustra a sua vida: vítima dos temores da ameaça da tirania que representava e dos sentimentos contraditórios que a sua doxa despertava, vítima das intrigas que semeou, envolvido, ambiguamente, em roupas de cortesâ, ou pura e simplesmente apanhado em fuga depois de saciar o seu eros. Um dia chegou em que o sonho fatalmente se cumpriu, esfumada, de todo, a influência de Sócrates sobre uma natureza promissora que por prazeres, adulação e cupidez se desintegrou numa desordem de alma e de acção. 


\section{DECADÊNCIA NA CORTE PERSA: UM SOBERANO \\ INCONSTANTE E UMA RAINHA-MÁE VINGATIVA NA \\ VIDA DE ARTAXERXES}

CARMen SoAres

Obras de confesso valor pedagógico e moral, as Vidas de Plutarco oferecem, quase em exclusivo, retratos de grandes nomes da história grega e da romana. ${ }^{1}$ Estas figuras, recheadas de virtudes, mas não isentas de defeitos, são heróis que cumprem uma missão educativa plena. Pela complexidade do seu ethos, despertam no leitor o desejo de imitar o que têm de melhor e ensinam-no a usar a razão para controlar as mais nefastas paixôes de que também eles são exemplo. ${ }^{2} \mathrm{~A}$ excepção a essa galeria greco-romana reside precisamente na figura de um soberano persa, Artaxerxes II (404-359 a. C.), objecto de reflexão do presente estudo. ${ }^{3}$ Assim, Plutarco brindava a sua vasta galeria de heróis pátrios com um toque de exotismo bárbaro. Ontem como hoje, o confronto com o 'outro', aquele que não comunga da cultura do 'eu', constitui uma estratégia indispensável à construçáo da(s) identidade(s). Nada melhor para que o leitor das biografias perceba os traços identitários de

${ }^{1} \mathrm{Ph}$. Stadter tem contribuído para aclarar essa dimensão pedagógica das Vidas, obras que funcionam, como o autor afirma, "as a mirror; a mirror not of outward appearance, but of inner person, of arete and of ethos" (2003/2004: 89-96, citação da p. 89). Ainda a propósito desta temática, veja-se o seu estudo 2000: 493-510.

${ }^{2}$ Cf. Ph. Stadter 2003/2004: 95.

3 Para uma análise sobre o período histórico do seu reinado, vide P. Briant 1996: 631-700. 
uma herança cultural greco-romana do que ser-lhe oferecida uma imagem, ainda que necessariamente padecendo de interferências da subjectividade do narrador (um greco-romano), desse universo cultural diverso. ${ }^{4}$

No caso concreto da corte persa dos finais do séc. $\mathrm{V}$ e inícios do IV a. C., o paradigma ético oferecido ao leitor de Plutarco é, no geral, negativo e decadente. Além das numerosas demonstraçóes de uma conduta condenável, patentes em vários episódios constantes da história, considero particularmente significativo de um retrato pejorativo do Bárbaro o juízo emitido pelo escritor a propósito da incapacidade de o monarca impedir a fuga de Gregos aliados de Ciro. Semelhante fracasso ilustra bem, nas palavras do biógrafo, que no que respeita o ouro, a luxúria e as mulheres o poderio do rei dos Persas era muito, mas no restante não passava de aparência e vã glória (20. 1).

Ao longo dos trinta capítulos que compóem a Vida de Artaxerxes, encontramos uma teia bem montada de relaçóes inter-familiares, fundamentais para o desenho do retrato do soberano persa. São várias as figuras que se destacam desse mundo de afectos e ligaçóes, todas elas provenientes do ciclo dos familiares mais chegados: a mãe (Parisatis), a primeira esposa (Estatira), o irmão (Ciro) e os filhos potenciais sucessores ao trono

${ }^{4}$ Dos inúmeros títulos publicados sobre a distinção Grego ou Romano/Bárbaro na Antiguidade (e alguns em Plutarco), limito-me a destacar os seguintes: H. Bacon 1961, B. Cunliffe 1988; A. G. Nikolaidis 1986; P. Georges 1994; T. Long 1986; C. Soares 2005; T. S. Shmidt 1999. 
(em especial Dario e Oco). ${ }^{5} \mathrm{Um}$ dos aspectos mais interessantes sobre a forma como Plutarco articula essas personagens com o protagonista da história e as estratégias discursivas para fazê-lo reside, quanto a mim, no facto de utilizar um mesmo modelo nos diversos casos. E este modelo pode ser apelidado de "discurso do engano". Ou seja, a história começa por apontar num sentido, mas o decorrer da mesma acaba, inevitavelmente, por revelar-se o inverso desse percurso original. Em suma, trata-se de criar expectativas que acabam sempre por sair frustradas. Não esqueçamos que, ao recorrer a este processo discursivo, o autor de Queroneia se inseria na mais pura linha da poética aristotélica. Conforme escreveu o Estagirita, aprende-se algo, se os elementos resultam ao contrário do esperado (Retórica, 1412 a 6). Como o próprio reconhece, o engano desempenha uma função inegável na produção das expressóes 'elegantes' (asteia).

Esta constante inversão de marcha no caminho inicialmente trilhado confere à história uma certa tensão dramática, aspecto que se traduz não só ao nível dos acontecimentos, mas também do discurso, o mesmo é dizer, da forma de traduzir aqueles por palavras. ${ }^{6}$ Consideremos, pois, os exemplos mais nítidos desse discurso do engano, passos essenciais ao revelar de uma ética em que prima a decadência de um dos principais valores da corte persa: o culto da verdade. De facto, o testemunho grego mais antigo desse pri-

${ }^{5}$ Sobre o retrato de Artaxerxes, vide D. P. Orsi 1988.

${ }^{6}$ Sobre as relaçóes entre a obra de Plutarco e a tragédia, vd. L. Guillén Selfa 1997 e Ch. Pelling 1997. 
mado da aletheia, Heródoto - apelidado de filobárbaros pelo próprio Plutarco (Moralia 857 a), precisamente devido ao respeito e admiração que nutria pelas tradiçóes dos 'outros' (os Bárbaros) - registou para a posteridade essa característica identitária dos Persas, afirmando: ${ }^{7}$

Dos cinco aos vinte anos, ministram aos filhos três conhecimentos apenas: montar a cavalo, atirar com o arco e dizer a verdade.

Nada mais condenável, no seu ponto de vista, do que faltar à verdade, e, em segundo lugar, contrair dívidas.

O que vamos detectar na actuação dos principais intervenientes da biografia de Artaxerxes II (o próprio, a mãe, a esposa, o irmão e os filhos), é um defraudar sucessivo de expectativas, o mesmo é dizer a passagem do que se tinha por verdades a enganos. Consideremos, de seguida, as principais etapas dessa retórica do engano.

Apesar de o matrimónio de Artaxerxes, até à entronização conhecido pelo nome de Arsica, com Estatira resultar no cumprimento da ordem dos progenitores para que casasse, partirá mais tarde do pai do noivo o desígnio de matar a nora (2. 2). Nesse momento valeu ao príncipe o apoio da rainha, permitindo-lhe salvar a mulher da morte. No entanto, não há sequência nesse

${ }^{7}$ Trad. de Maria de Fátima Silva, in J. R. Ferreira e M. de F. Silva 1994. 
laço de solidariedade entre mãe e filho. Na verdade Parisatis limitava-se a prestar um auxílio circunstancial tanto ao filho como à nora, pois, embora na sombra, a rainhamãe apoiará o filho predilecto, Ciro, nas suas ambiçóes futuras de usurpaçáo do trono ao então Artaxerxes II e, segundo Ctésias, terá mesmo sido ela a autora do homicídio da nora por envenenamento. ${ }^{8}$

No que se refere à ascensão de Arsica ao trono, a qualidade de filho primogénito não lhe garante o direito de ser o herdeiro incontestado do pai. Semelhante expectativa, à partida legítima, é contrariada em duas frentes (pela mãe e pelo irmáo). A rainha, incapaz de disfarçar o favoritismo que sente pelo filho mais jovem (2. 3), procura dissuadir o marido de transmitir a realeza a Arsica, alegando que aquele nascera antes de ele ser rei, enquanto Ciro viera ao mundo já o progenitor estava investido da soberania. Não obstante o suserano se encontrar moribundo, a sua vontade cumpre-se, restando a Ciro o lugar de sátrapa da Lídia. Assim como sucede com Parisatis, também as expectativas do irmão de Artaxerxes saem defraudadas. De facto, graças à denúncia de um sacerdote, o plano para derrubar o futuro rei do trono (fazendolhe uma emboscada durante a entronização no templo, capturando-o e matando-o) fracassa (3.4).

Num ambiente em que a traição se pune com a morte, perante a denúncia das intençóes de Ciro,

${ }^{8}$ A propósito do uso das fontes em Plutarco, não esqueçamos que a natureza ética da biografia justifica a presença de elementos ficcionais nas Vitae, como bem notou A. G. Nikolaidis 1997. Sobre o tratamento dado às fontes (Xenofonte, Ctésias e Dinon), vide D. P. Orsi in M Manfredi 1996: XXIX-XXXIV. 
Artaxerxes nutre o desejo de matá-lo. Contudo o motivo do engano repete-se, uma vez que não se verifica a execução do pretenso usurpador do trono. Invertem-se os papéis, cabendo desta feita à mãe o papel de suplicante e a Artaxerxes o de benfeitor. Por meio de gestos e palavras carregadas de emoção a rainha-mãe dissuade o filho de cumprir a vontade de liquidar o rival (3. 6).

Já para o final do seu longo reinado, o velho Artaxerxes II assiste a uma "reedição" da disputa pelo poder entre os herdeiros ao trono. Os protagonistas são agora os seus próprios filhos, situação em que o rei não deixa de perceber o paralelismo com a luta que teve de travar com o irmão. ${ }^{9}$ De novo a ambição desmesurada de um dos príncipes, Oco, vai pôr em causa a legítima ascensão do primogénito ao poder, Dario (26. 1). O pretendente rebelde, numa versão mais decadente do tio, qualificado de intrépido (oxús) e violento (bíaios, 26. 2), procura também ele o apoio de uma figura feminina. Não recorre, como Ciro, à mãe, mas continua a buscar auxílio na esposa do rei, neste caso a sua irmã Atossa. À imagem de Artaxerxes - que, transgredindo a lei (parà tòn nómon, 27. 2), em particular a dos Helenos (Hellenon kai nómous, 23. 5), ao desposar duas filhas, incorre em duplo incesto - Oco procura aliciar Atossa a influenciar o rei-pai-marido a nomeá-lo seu sucessor. Os argumentos usados para persuadir a rainha teriam sido, ao que cor-

${ }^{9}$ Repare-se, aliás, que é por recear que, tal como fizera Ciro, também Oco lance o reino numa onda de guerra interna que Artaxerxes toma a iniciativa de nomear seu sucessor o filho mais velho, Dario (26. 4). 
ria, de ordem carnal e de prestígio social (26.3). Ou seja, prometera desposá-la, depois de o pai morrer, o que lhe permitiria manter o estatuto de que gozava no presente. Mesmo antes de se verificar um tal desfecho, Oco teria mantido um relacionamento físico com Atossa.

Contudo o carácter dos protagonistas desta segunda disputa pelo trono da Pérsia, revelando traços mais vincados de vícios como a inveja e a ambição pelo poder, coadjuvado pela inconstância do monarca reinante, determina um desenlace diferente do ocorrido na história da subida de Artaxerxes ao poder. Rezava a tradição persa (nomos, 26. 5 e 27. 3) que o rei satisfizesse um pedido formulado pelo herdeiro nomeado seu sucessor. Quer o conteúdo do desejo de Dario quer a forma como o pai o cumpre encerram o rastilho da discórdia. O pedido do filho obriga o progenitor a privar-se de um dos bens que mais apreciava e que zelosamente guardava da cobiça de terceiros: as mulheres do seu harém (27. 1). Artaxerxes, por seu turno, reincide em nova transgressão do nomos pátrio, uma vez que, embora conceda a Dario a concubina pretendida, a Iónia Aspásia, confere-lhe de seguida o cargo de sacerdotisa de Ártemis de Ecbátana. Isto é, sujeita ao voto de castidade, Aspásia não poderia unir-se a Dario, privando-o da honra a que tinha direito. Conforme reconhece Tiribazo, principal conselheiro de Dario na revolta contra o pai, quem era capaz de transgredir (pseusámenos) uma lei inviolável (ápseuston...nómon) dos Persas, como fizera Artaxerxes por causa de uma mulher grega, não seria digno de confiança (ou...pistós) quando se tratasse de promessas 
mais importantes (28. 2). Tendo fracassado na sua tentativa de assassinar o pai e de se apoderar de imediato do trono, Dario acaba por ser condenado à morte. Das duas versóes que Plutarco apresenta para este desfecho (29), uma delas imputa mais um pesado crime ao rei bárbaro: a autoria do filicídio.

Que imagem vai, então, o leitor construindo deste monarca persa? Tal como sucede com a maioria dos 'heróis' das Vidas, não é possível estabelecer um fio condutor único, apontando no sentido da virtude ou do vício, mas deparamos com ramificações nos dois sentidos. Assim, Plutarco começa por confrontar-nos, no início e no final do reinado, com um retrato de monarca clemente. Nos primeiros tempos de governaçáo, esse perfil foi-se construindo através de uma maior proximidade relativamente aos súbditos, de uma liberalidade na concessáo de honras e favores, da supressão da insolência e do sadismo das puniçóes (4. 4). Findo o seu reinado, e por comparaçáo com o período sangrento e cruel do sucessor, a imagem que deixa é de benevolência (prãos) e preocupação com os súbditos (philypékoos, 30. 9). Porém, várias são as inversóes registadas, ao longo do seu reinado, em relação a esse modelo inicial de conduta. Antes de mais, há que lembrar que o autor tem o cuidado de registar que a imagem de bom monarca não correspondia a um entendimento unânime. Uma corrente de opiniáo minoritária, opositora da governação de Artaxerxes, interpretava a sua méllesis não como clemência, mas como falta de firmeza, conforme se deduz das qualidades que esses indivíduos reconhecem ao 
opositor que apoiam, Ciro (6. 1), e que, se subentende, faltam ao rei - inteligência, distinção guerreira, companheirismo (philétairon), coragem (phrónema) e ambição (philotimia). Aliás, a versão que Plutarco apresenta do comportamento de Artaxerxes perante a ofensiva de Ciro, baseada em rumores (phêmai kai lógoi, 7. 1) e fontes anónimas (hôs phasi, 7. 3), atesta a cobardia do rei, que não se decide a combater, que foge ou esconde-se na Pérsia. Não obstante, a frustração das expectativas criadas vai sendo uma constante na narrativa e, ao contrário da crença dos aliados de Ciro, Artaxerxes não revela ser um comandante inferior, conforme atesta a surpresa que nos aliados gregos do insurrecto causa a forma ordenada como o exército do rei avança (7. 5).

Mais tarde, por ocasião de uma expedição militar movida contra os Cadúsios (24), o soberano dará mesmo mostras da capacidade de inspirar confiança nas suas tropas e de colocar as necessidades destas em campanha acima do apreço por bens pessoais. Ao despojar-se das suas luxuosas vestes régias (que substitui pelo equipamento do soldado de infantaria) e desmontar do cavalo para caminhar a pé ao lado dos seus homens, Artaxerxes mostrava que, ao contrário do que julgava muita gente, a cobardia e a fraqueza não provêm da luxúria e da magnificência, mas sim de uma natureza viciosa, vil e orientada por opinióes perversas (24. 9). Este companheirismo e abnegação do rei transmitem aos guerreiros o ânimo necessário para não sentirem a fadiga das longas marchas exigidas pela expedição (24. 10-11). Outra marca no texto dessas mesmas características de bom general 
resulta do facto de o rei não ter hesitado em sacrificar as árvores frondosas do bosque de uma mansão sua, permitindo assim aos seus homens aquecerem-se durante a noite e recuperar forças (25. 1-2).

Contudo, o carácter ambivalente do monarca vai-se evidenciando na medida em que a essa imagem de comandante exemplar se contrapóe o seu reverso. Corroído por suspeitas infundadas de que o fracasso da campanha despertara no povo um sentimento de desprezo pela sua pessoa, Artaxerxes dá mostras de uma insegurança que acaba por se traduzir em crueldade gratuita e cobardia. Acicatado por um sentimento de inveja em relação aos nobres que o rodeiam e pelo receio de perder o poder que detém, condena muitos dos seus cortesãos à morte, confirmando a veracidade da máxima de que a cobardia é a característica mais sanguinária dos tiranos (25.4).

Deixando a esfera militar, passemos à imagem de juiz clemente, facilmente abandonada quando o rei receia ver diminuído o seu mérito (aretê). De facto, ao invés do comportamento revelado no início do reinado - altura em que proibia que os castigos se transformassem na usual demonstração do prazer da vingança (4. 4) - o suserano dará mostras da mais crua brutalidade num dos castigos a aplicar a dois detractores do seu bom nome. $\mathrm{O}$ crime cometido pelos súbditos condenados à morte teve lugar na famosa batalha de Cunaxa, ocasião em que Ciro, derrotado pelas tropas fiéis ao rei, encontra a morte. Plutarco regista duas versóes dos acontecimentos. Segundo o testemunho de Xenofonte, relatado de 
forma bastante sucinta, o rebelde perecera ou às mãos do monarca ou de um soldado Cário (10. 3). Já Ctésias apresenta um quadro em que náo coube ao rei desferir o golpe fatal. E, embora goze sobre a fonte anterior da vantagem de ter sido médico na corte de Artaxerxes, o autor de Queroneia reconhece-lhe a pecha de o seu discurso se afastar muitas vezes da verdade, tendendo para a fiç̧ão e o teatral (6. 8). A façanha de aniquilar o rival do monarca, segundo esta fonte, teria sido partilhada por Mitridates (um jovem persa, que, sem saber de quem se tratava, atingira o príncipe numa das têmporas, 11.5) e um soldado cáunio ou cário (responsável pela queda de Ciro do cavalo abaixo, acidente que provoca o embate da ferida contra uma pedra no solo e a morte imediata da vítima, 11. 10). ${ }^{10}$ Emissários do rei acorrem ao local, para confirmar a morte do revoltoso e, cumprindo um ritual (nomos) persa de humilhação do vencido, cortar-lhe a mão direita e a cabeça, entregando esta última a Artaxerxes (13). Empunhando esse troféu da vitória diante dos seus homens, o monarca não só consegue travar a retirada, como passa a mensagem de ter sido ele o autor do feito. ${ }^{11}$ Procurando "comprar" o silêncio dos verdadeiros homicidas, envia-lhes presentes (14). Mas tanto um como o outro são tomados de soberba, acabando por

${ }^{10}$ Mais adiante no texto, Plutarco apelida o responsável por este acto náo de cáunio, mas de cário (14. 6 e 9).

${ }^{11}$ Como se lê mais adiante (16. 2), a versão oficial dos factos, isto é, aquela que Artaxerxes desejava passar tanto aos seus compatriotas como aos Gregos envolvidos no combate na qualidade de mercenários, era de que ele e o irmão se haviam ferido mutuamente, tendo Ciro perecido e ele náo. 
cometer o "crime" que lhes valerá a morte. Isto é, dizem a verdade. Cumprir aquele que era um dos princípios basilares da formação dos Persas, a aletheia, e ser punido por isso só pode ser entendido como uma demonstração do ambiente moral decadente vivido na corte. Contrariando a imagem de juiz clemente, Artaxerxes ordena a aplicação a Mitridates de uma tortura que só lhe traz a morte ao fim de dezassete dias de atroz sofrimento. ${ }^{12}$ Menos impiedosa era a sentença destinada ao Cário, a decapitação. No entanto, a falta de firmeza do rei, aliada à forte influência exercida pela mãe nas suas decisóes, levam-no a abdicar de uma condenação sumária, mas simples, para entregar o condenado ao arbítrio de uma rainha vingativa e cruel (assunto que retomaremos mais adiante).

Sem sairmos do contexto da batalha de Cunaxa, percebemos pelo respectivo desenlace que estamos forçosamente perante a frustração das expectativas de uma das partes (Ciro). Recordemos que a sua crença na vitória era motivada por: esperança no apoio da mãe (2. 3) e na sua capacidade de afastar as suspeitas do rei sobre si (4. 3); confiança nas forças aliadas (6. 2), conseguidas na Pérsia e nas terras vizinhas, e no apoio solicitado aos Lacedemónios (6. 3); elevada auto-estima e um desprezo evidente pelas capacidades do irmão e adversário (6. 4).

Ainda do ponto de vista da rede de apoios militares

${ }^{12}$ Veja-se a descrição pormenorizada da decomposição e putrefacçáo do corpo vivo de Mitridates, por acção de vermes e insectos (16. 3-7). 
necessários ao bom sucesso de uma campanha militar, o rei revela eleger como princípio basilar das alianças estabelecidas o seu interesse pessoal. Ou seja, ao invés do que fazia supor a ética da philia, os acordos firmados pelo monarca náo assenta na inter-ajuda. $\mathrm{Na}$ verdade ele sente-se desobrigado de retribuir o auxílio recebido, assim que o aliado lhe deixa de ser útil. Foi precisamente desse modo que se comportou com o espartano Antálcides (21-22). Em reconhecimento pelo tratado de paz firmado entre Persas e Gregos (em 386 a. C.), no qual Antálcides exercera o papel de embaixador, favorecendo de forma nítida o Bárbaro, Artaxerxes distinguiu-o com as maiores honras. No entanto os estatutos de hóspede (xenos) e de amigo (philos) só lhos reconhece enquanto Esparta mantém entre as cidades gregas a posição de líder (22. 6). Assim que essa hegemonia, após a batalha de Leuctras (371 a. C.), é transferida para Tebas, o senhor da Pérsia corta relaçóes com o antigo aliado.

A mesma falta de palavra, isto é, a facilidade em faltar à verdade, incorrendo na falsidade, surge na história de Tiribazo. De facto, nem mesmo os seus compatriotas podem confiar no rei, de quem se esperava fosse guardião da aletheia. Por duas vezes Artaxerxes não cumpre as promessas de casamento feitas ao súbdito. A razão para semelhante incumprimento é a mesma em ambos os casos: a sobreposiçáo do seu interesse pessoal ao do outro. Ou seja, depois de lhe ter prometido, sucessivamente, a mão das filhas Améstris e Atossa, recusa o dom, desposando ele próprio as noivas (27. 7-9).

Também na esfera doméstica, Artaxerxes dá 
mostras da mesma tendência para as vinganças cruéis. A escrava sobre quem recai a suspeita de envenenamento de Estatira (sob ordens ou não de Parisatis) condena-a à morte por esmagamento do crânio entre duas pedras (19. 9). Esta era, ainda, a forma corrente de os Persas executarem os envenenadores ao tempo de Plutarco.

Centremos, agora, a nossa atenção na figura da rainha-mãe. Diferentemente do que fazia supor a sua intervenção, salvando a vida da nora (2. 2), Parisatis tornar-se-á, segundo a versão de Ctésias, na responsável pela sua morte (19.5). O ódio a Estatira (misousa...Státeiran, 6. 8) é motivado pelos ciúmes que tem do poder exercido por ela junto do rei (19.1). As duas mulheres estabelecem entre si uma nítida relação de rivalidade. A sogra procura reduzir ao mínimo o tempo de contacto da nora com o filho (17.4), estratégia que lhe permitiria diminuir gradualmente a influência desta nas decisóes daquele. Incapaz de dominar o ódio secreto e os ciúmes que sente por Estatira (19. 1), tece um ardiloso plano para lhe pôr termo à vida. Durante uma das refeiçóes que, mais por razóes de etiqueta do que por particular afecto, toma em conjunto com a nora, serve-lhe a metade envenenada de uma ave, consumindo ela a carne não contaminada (19. 3-5).

A propósito da figura central da mãe na vida de Artaxerxes, podemos afirmar que Plutarco recorre para o seu retrato a um património mítico particular: o motivo literário da rainha bárbara e vingativa. Perante a ausência de uma confissão do autor quanto aos intertextos subjacentes à construção deste motivo, considero 
um exercício especulativo pouco produtivo, em termos de fiabilidade dos resultados, enveredar por uma investigação desse tipo. Esteja ou não Plutarco a transmitir histórias recolhidas em Xenofonte, Ctésias, Dinon ou outros, a verdade é que a estrutura a que obedecem vem literariamente tratada na obra de um antecessor que mereceu críticas acérrimas de Plutarco: Heródoto (em De malignitate Herodoti). $\mathrm{O}$ polígrafo não escondeu, no entanto, a admiração que tinha pela faceta de contador de histórias de Heródoto, a quem elogia a graça (charis) e o talento (deinótes) revelados na sua narrativa (tois diegêmasi, $874 \mathrm{~B})$.

Embora evocando um referente necessariamente anterior, no tempo, ao agora tratado por Plutarco, as Histórias reúnem um elenco demasiado representativo para ser ignorado em matéria de retrato da rainha bárbara. Tómiris, a Masságeta (1. 212-215), Nitócris, a Egípcia (2. 100) e Améstris, a Persa (9. 112), todas comungam das características de um mesmo estereótipo - o da soberana bárbara, social e politicamente poderosa, que pune de forma cruel e selvagem (aos olhos do público grego) quem contra si comete actos julgados criminosos. Basta uma evocação sumária dos factos para ter presente que todas elas foram atingidas no âmago da sua identidade feminina, ora como mãe, como irmã ou como esposa. A rainha-viúva dos Masságetas assistiu à humilhação pública do seu herdeiro às mãos do inimigo, Ciro, fundador do reino medo-persa. Morto o autor de semelhante ultraje, a soberana mergulha-lhe a cabeça num odre de sangue. Nitócris, irmá do faraó 
assassinado, executa os autores do crime. Améstris, esposa de Xerxes, cega de ciúmes, ordena a mutilação da cunhada, objecto do afecto do rei. Para além da desfiguração do rosto (através do corte da língua, das orelhas e do nariz), a vingança passa também pela ablação dos seios. É precisamente a prática deste tipo de mutilação que me faz juntar a esta galeria de mulheres vingativas bárbaras uma Grega. Refiro-me a Feretima, máe do tirano grego de Cirene (4. 200-205). Também ela encarna a figura da máe vingativa. Aos responsáveis pelo homicídio do filho manda empalá-los à volta da muralha de Barca, as quais guarnece com os seios cortados às respectivas esposas.

Importa destacar deste último passo uma máxima referida a propósito do fim de Feretima, devorada viva por vermes: as vinganças humanas demasiado excessivas são odiosas aos deuses (4. 205). Semelhantes comportamentos, pode deduzir-se, náo se ajustam à mentalidade grega. $\mathrm{O}$ excesso, como exemplificam à saciedade as tragédias áticas, constitui, aliás, um dos principais erros do herói trágico. Vejamos, agora, em que medida Plutarco faz uso do 'fundo mítico' da mulher poderosa e vingativa.

É na figura da rainha-mãe que se detectam os traços carregados desse desenho. Desde a apresentação do seu carácter que o público da Vida de Artaxerxes fica a saber tratar-se de uma mulher de natureza colérica e bárbara na manifestação da ira e do ressentimento (physei barythymos oûsa kai bárbaros en orgais kai mnesikakiais, 6. 8). E os exemplos confirmativos desse temperamento sucedem-se.

$\mathrm{Na}$ condição de mãe vingadora, chama a si a 
deliberação da pena a aplicar aos mais directos implicados na morte do filho favorito, Ciro: o Cário, atrás referido, e Masabates, eunco que cortara a mão e a cabeça ao príncipe morto. Da pena infligida ao primeiro importa reter o seguinte: a ambição desmedida, ou hybris, fê-lo aspirar ao que estava para além dos seus limites (hypèr autón, 14. 8). Parisatis, descontente com a pena leve sentenciada pelo rei, convence-o a transferir para si a deliberação da mesma. O fim que espera o condenado é de uma atrocidade exemplar: dez dias de tortura (esticado num cavalete), rematados pelo vazar dos olhos e versão de bronze fundido para dentro dos ouvidos. Mas a cólera bárbara da rainha-mãe estende-se ainda a mais duas figuras. Uma delas, o já referido eunuco Masabates. Outra, Estatira, moralmente implicada na execução de aliados gregos do insurrecto, o general espartano Clearco e boa parte dos seus homens.

Uma vez que quer um quer outra não caíram em desgraça perante Artaxerxes, Parisatis tem de lançar mão de toda a sua inteligência (thymósophos gynê, 17. 3) e dissimulação (prospoiouméne, 17. 5) para obter a desejada vingança. Depois de ganhar numa aposta de jogo o eunuco responsável por, no estrito cumprimento das ordens do seu suserano, cortar a mão e cabeça de Ciro, manda esfolá-lo vivo e espetar o seu corpo em três estacas. Este e todos os anteriores actos de vingança de Parisatis, convém enfatizá-lo, são claramente denunciados por Estatira como 'cruéis e injustos' (omôs kaì paranómos, 17. 9). Quanto ao envenenamento da esposa de Artaxerxes (acima referido), que Plutarco classifica de 
'acto terrível' (deinòn érgon, 13. 9) e não acredita ter sido planeado por Parisatis, o sofrimento enorme que provoca na vítima aproxima-o do rol de torturas que vão desfilando diante do olhar da imaginação do público ao longo da história.

Em suma, ao dar conta de uma corte persa sujeita a ambiçóes cruéis, invejas e falsidades, constantemente abalada por assassínios e execuções repletas de horrores, Plutarco inscreve-se numa corrente de opiniáo contemporânea do reinado do próprio Artaxerxes II. Reporto-me à ideia da "decadência persa", começada a difundir na Grécia pelo orador ateniense Isócrates. ${ }^{13}$

${ }^{13}$ Veja-se, a este propósito, dois artigos de P. Briant 1989 e 


\section{Demotikos e Demokratikos na Paideia de Plutarco}

José Ribeiro Ferreira

Este trabalho, baseado sobretudo nas Vidas Paralelas, pretende mostrar que o herói de Plutarco, embora homem da pólis e seu servidor, encarna também todos os seus valores: humano, polido, amável, cortês, culto, benevolente, romano ou grego - uma noção que está próxima do ideal do homem da cidade e que corresponde ao próprio ideal de civilização e que não está longe afinal de uma visão da doçura como virtude democrática. Por outro lado, procurar-se-á perceber por que razão Plutarco dá ao homem de modos simples e afáveis o apelido demotikos ("amigo do povo") ou "democrático", associando a palavra a philanthropia. Por exemplo, para designar a simplicidade e afabilidade de Agesilau usa os termos demotikos e philanthropos (Ages. 1.5). Na Vida de Luculo (44.5), ao comparar as refeiçóes de Luculo com as de Címon, contrapóe a do primeiro, faustosa como a de um sátrapa, à do segundo, democrática (demokratike) e generosa (philanthropos). Por outro lado, para designar actos humanos e benevolentes, aparece a associação dos adjectivos "helénico", doce (praos), humano (philanthropos).

Exalta Plutarco as épocas áureas da Grécia e de Roma, e povoa as Vidas paralelas de heróis, cujas virtudes convidam à imitação: frugalidade, simplicidade, 
honestidade, diligência, temperança, inteligência, autodomínio, coragem, integridade, justiça, amor à pátria e amor à liberdade. ${ }^{1}$

Este conjunto de qualidades — ora de índole militar, ora de índole mais intelectual — segundo estudo de C. Panagopoulos, ${ }^{2}$ pode agrupar-se nas seguintes virtudes principais: engenia, riqueza, amor da glória, bons costumes, espírito de família, doçura, coragem, justiça, inteligência, excelência; ou ser reduzido, na opinião de Françoise Frazier (1996: 173-273), a quatro virtudes principais, tanto para as Vidas como para os Moralia: coragem (andreia), inteligência (phronesis), justiça (dikaiosyne) e autodomínio (sophrosyne). Encaminha-nos para esta última listagem o De audiendis poetis - um tratado dedicado à educação, à paideia - onde Plutarco recomenda que se ensine aos jovens a andreia, a sophrosyne, a dikaiosyne (30D) e a phronesis que é, na opinião de Homero, a «qualidade mais adequada a um deus e a um rei» (32A).

Plutarco, ao enumerar estas virtudes, pensa num ideal grego, mas, homem integrado no império romano, tem consciência de que Hélade e Roma formavam um todo cultural. Se defende a civilização que, por essência, é grega - e que transparece em muitos dos seus heróis,

${ }^{1}$ Neste trabalho baseio-me sobretudo nas Vidas Paralelas, por interessarem mais as virtudes em acção e por os heróis aí biografados constituírem paradigmas que sempre exerceram forte fascínio ao longo dos tempos. Não esquecerei evidentemente os Moralia, e para eles remeterei a cada passo.

2 Estudo realizado a partir das inscriçóes citadas nos Tratados morais 1977: 197-235. 
através de virtudes por eles praticadas -, esses valores impregnaram profundamente a cultura romana, até construírem uma cultura homogénea.

É conhecimento adquirido que Roma, apesar de conquistadora, recebeu a cultura e muitos dos valores da Grécia, como refere Horácio, no famoso passo das Epistolas (Epist. 2.1. 156-157) :

Graecia capta ferum victorem cepit et artes Intulit agresti Latio.

Plutarco sublinha essa atracçáo da cultura grega sobre os Romanos. Dou, como exemplo, o seguinte e significativo passo da Vida de Marcelo, onde, na apreciação das qualidades do estadista, a moderação e a humanidade se encontram ao mesmo nível do domínio e interesse pela cultura e língua gregas (1.3):

Era moderado (sophron), humano (philanthropos) e amante da cultura e literatura gregas, a ponto de honrar e admirar aqueles que as cultivavam com êxito; mas ele próprio, devido às suas ocupaçóes, náo as podia exercer e aprender quanto era seu desejo.

Para Plutarco, o império romano é cadinho e garante da perenidade dessa civilização greco-romana que se foi formando aos poucos e que ele próprio cimenta definitivamente, ao aproximar por sistema a biografia de um romano da de um grego, exaltando as qualidades e virtudes de um e de outro e denunciando os seus defeitos. 
E um dos traços mais salientes e mais exaltados dos heróis biografados por Plutarco reside na sua doçura e humanidade, a característica doçura grega, «essenciellement une vertu de sociabilité, de tolérance et d'indulgence», como a define J. de Romilly (1979: 328). Depois de uma pormenorizada análise dessa qualidade grega - que se aproxima da clementia romana, mas que com ela se náo confunde, por ser mais ampla -, a helenista francesa considera ser nos fins da literatura grega, com Plutarco, que encontramos o apogeu dessa noção de doçura: todas as tradiçôes a ela relativas, todas as palavras para a designar, todas as formas de a conceber vêm de certo modo confluir na obra do filósofo de Queroneia (1979: 278).

Qualidade que se pode educar, a doçura intervém praticamente em todos os aspectos da vida do herói: aparência, comportamento, modo de vida ou acçôes. E assim presente em todo o lado, tudo comanda, aparecendo como ideal de vida essencialmente grego, traduzido no próprio vocabulário: praotes "mansidão", "doçura"; epieikeia (ou o adjecttivo epieikes) que se aproxima de "igualdade" ou indulgência; philanthropia ou philanthropos "humanidade". ${ }^{3}$ As duas primeiras, virtudes de carácter mais pessoal, impregnam o comportamento e manifestam contenção física. ${ }^{4}$ A philanthropia,

${ }^{3}$ Os termos praotes (contabilizando as palavras da família) e epieikeia (ou o adjecttivo epieikeios) aparecem mais de 100 vezes cada um; philanthropia e philanthropos são utilizados cerca de 50 vezes.

${ }^{4}$ Quanto à praotes - que é antes de mais uma resistência interior à cólera e à violência, aos prazeres (cf.Brut. 1.3) — o autor 
pelo contrário, traduz uma postura ou uma actuação que se volta para fora, para o convívio social, o contacto com os outros.

Nas Vidas paralelas, o herói não é um homem só, mas surge sempre como responsável por outros, um chefe que deve velar pela salvação do exército e do estado, cuja prudência protege e cuja resolução galvaniza os outros. Talvez por isso a virtude suprema nas Vidas seja a dikaiosyne, que se aproxima da philanthropia, mas também do que exprimem adjectivos como demotikos e hellenikos (e suas substantivaçôes) - ou seja cultura, afabilidade, humanidade, benevolência, sociabilidade.

Os termos philanthropia ou philanthropos, e outros que com estes se relacionam, - utilizados cerca de três centenas de vezes na obra de Plutarco ${ }^{5}$ - exprimem uma qualidade que, virada para o exterior, se dilata até abraçar a humanidade inteira. Com ligação indissociável à civilização e ao helenismo e eminentemente sociável, traduz um modo de viver agradável e educado com os amigos, tendendo no campo das relaçôes humanas para a philia, ${ }^{6}$ e, segundo as circunstâncias, pode tomar cores de afabilidade, de cortesia, de liberalidade, de gentileza, de bondade ou de clemência. Assim Fó-

mostra que ela cobre o domínio físico e moral, reveste aspectos intelectuais e se associa à legalidade.

5 Mais especificamente, segundo consulta informática ao T.L.G., temos 293 ocorrências: 54 de philanthropia, 235 de philanthropos ( 45 dos quais na forma adverbial) e 4 de philanthropeuma

${ }^{6}$ Jr. H. Martin 1961: 164-175. Na p. 174, considera que a philanthropia é a virtude por excelência do homem civilizado. 
cion, embora rude, inflexível e inexorável quando se tratava de medidas propostas para o bem da pátria, era no resto «benevolente para todos, acessível e humano».7 Por outro lado, segundo um passo dos Moralia «quem é sociável, humano, patriota, cuidadoso do bem público e verdadeiramente político ${ }^{8}$ dedica o seu tempo às tarefas da pólis.

Plutarco é sensível a tudo o que é solidariedade humana. Segundo J. de Romilly (1979: 276), é o primeiro a usar o verbo synanthopeo "ser homem em conjunto”. Um passo dos Preceitos Políticos (Moralia 823B) informa que Hérmon nunca foi importuno com os serviçais, nem sobressaía pelo luxo e sumptuosidade, mas procurava ser igual aos outros - no modo de vestir, no género de vida, na educação dos filhos, na toalete da mulher - para ser homem igual aos outros ou em conjunto com os outros (synanthropein). Por outro lado, Plutarco, no tratado Acerca do amor fraterno (Moralia 479C), critica o carácter solitário (aphilanthropos): defende a necessidade de o homem procurar a amizade e a companhia das pessoas, viver em sociedade, já que, sem contrariar a natureza, ninguém pode viver sem amigos, sem relaçôes de uns com os outros, solitário. ${ }^{9}$

Falhar no que respeita à humanidade é defeito que o adjectivo apanthropos estigmatiza. ${ }^{10}$ Assim Plu-

${ }^{7}$ Phocion 10.7: eumene ... kai koinon kai philanthropon.

8 796E.

9 Cf. ainda Mor. 1098D onde aparece a mesma censura ao aphilanthropos.

10 Encontramos o adjectivo em outros autores. E. g. Dionísio de Halicarnasso 6. 81; Apiano 7. 5. 28. 
tarco opóe a apanthropia à philanthropia: um passo da Vida de Dion (7.5) refere que este, enfraquecendo a tirania, fê-la parecer humana (philanthropos), retirando-lhe o que tinha de excessivamente inumano (lian apanthropon). A moderação, simplicidade e humanidade de Díon aparece sublinhada em outros passos, Apenas mais um exemplo: feito o relato da tomada de Siracusa e apontados a grandeza, o poder e a glória de Díon, Plutarco refere que este «se mostrava tão moderado no vestuário, nos serviçais, na mesa, como se vivesse na Academia com Platão e não no meio de chefes militares e de mercenários» (Dion 52.3).

Com ligaçôes estreitas com outra característica saliente dos heróis de Plutarco, a charis que exprime o tratamento agradável, ameno, recíproco entre o que é beneficiado e o que beneficia, ${ }^{11}$ a philanthropia intervém praticamente em tudo o que interessa no carácter do herói. Trata-se de uma tendência pessoal que se pode educar. Assim o sugere um passo do Banquete dos Sete Sábios (148D), em que a jovem Cleobulina-Eumétis, sagaz, hábil, inteligente e generosa (philanthropos), conseguia tornar o seu pai, Cleobulo, «mais doce para os seus súbditos e mais amigo do povo" (praoteros e demotikoteros).

O herói de Plutarco é assim um homem sociável, da pólis como sistema de vida e entidade formadora e educadora; não apenas o servidor dessa cidade, mas também a encarnação de todos os seus valores: humano,

11 Vide C. Meier 1987: 37. 
polido, amável, cortês, culto, benevolente, romano ou grego. Trata-se de uma concepção que está próxima do ideal do homem da cidade e que, segundo Frazier 1996: 274, corresponde ao próprio ideal de civilização. Não estamos longe afinal de uma visão da doçura como virtude democrática. Parece-me por isso ter razão J. de Romilly 1979: 279, quando sublinha que à tradição platónica de que o sábio suporta a adversidade praos, "com doçura" ou "com serenidade", Plutarco alia uma tradição diferente, expressa nos oradores áticos, que via na doçura uma virtude democrática. Não são raras as vezes em que Plutarco dá ao homem de modos simples e afáveis o epíteto de demotikos ('amigo do povo') ou demokratikos, associando estas palavras aos termos metrios, praotes, philanthropia e outras das mesmas famílias. Por exemplo, na Vida de Sólon refere que o Estadista ateniense, que pertencia a famílias aristocráticas, era um "homem do povo" (16.2: demotikos), que preferia a vida e a morte de um homem do povo (27.6: demotikos) e de um simples particular; observa ainda que a divindade, ao conceder aos Gregos serem em tudo moderados (metrios), parece ter feito nascer uma sabedoria prudente e demotike, nem real, nem brilhante (27.7-8).

Para sublinhar a simplicidade e afabilidade de Agesilau associa a palavra demotikos a philanthropia, referindo que o rei tinha um carácter "demótico e filantropo» — ou seja «simples e humano» —, e que à sua qualidade de chefe e de rei unia a simplicidade e a afabilidade da educação (to demotikon kai philanthropon). ${ }^{12}$ Por outro lado, em

12 Ages. 1.5. 
contraste com os outros reis que ostentavam riqueza e manifestavam desdém para com os que se lhe dirigiam, Cleómenes, pelo contrário, não ostenta qualquer fausto real, mas vinha ao encontro deles com grande simplicidade, estendendo-lhes a mão, conversando com eles e escutando as suas solicitaçóes, com aspecto alegre e afável (hilaros e philanthropos), a ponto de todos "ficarem agradados com os seus modos democráticos». ${ }^{13}$ Efeito oposto provoca Rómulo que não soube evitar o inebriamento do poder e do sucesso; pelo contrário, «seduzido pela prosperidade e cheio de orgulho insuportável, perdeu o aspecto simples (demotikos) e passou a pender para a monarquia que, em primeiro lugar, importunava e feria devido à ostentação de que se rodeava». ${ }^{14} \mathrm{Na}$ Vida de Luculo (44.5), ao comparar as refeiçóes de Luculo com as de Címon, Plutarco contrapóe a mesa do primeiro, faustosa como a de um sátrapa, à do segundo, democrática (demokratike) e generosa (philanthropos).

E assim os passos opóem as maneiras simples, afáveis, humanas ou demóticas à ostentação e aparato da monarquia ou riqueza. ${ }^{15}$ Outras vezes a oposição pode verificar-se entre demótico e moderado (metrios), por um lado, e o rigor e a dureza, por outro, como acontece num passo da Vida de Publícola 12. 1: o dirigente mostra-se demótico e moderado (metrios), como nomoteta, mas rigoroso e intransigente, no caso de crimes desmedidos.

${ }^{13}$ Cleom. 13.3.

${ }^{14}$ Rómulo 26.1.

${ }^{15} \mathrm{Cf}$. ainda Publicola $11.4 \mathrm{em}$ que o termo demotikos parece ter um sentido próximo de 'republicano' ou, talvez com mais propriedade, que vive num sistema náo autocrático. 
Mais surpreendente ainda é a admissão na obra de Plutarco de outra equivalência, também frequente nos oradores áticos, de uma doçura ateniense ou melhor grega. Traduz-se pela associação do adjectivo 'helénico' a praos e philanthropos. É o que se verifica na Vida de Filipomen. Aí, em 8.1, afirma que Arato fez crescer a confederação aqueia «em dignidade e em poder», unindo as póleis e praticando uma política «helénica e generosa». ${ }^{16}$

Por outro lado, para designar actos humanos e benevolentes, aparece a associação dos adjectivos "helénico", doce (praos), humano (philanthropos) - e advérbios correspondentes. Um passo da Vida de Marcelo fala dos procedimentos helénicos e doces dos Romanos para com os deuses e do seu constrangimento, ao verem-se obrigados, desencadeada a guerra, a enterrarem dois Gregos e dois Gauleses, por indicação dos oráculos sibilinos (3. 6):

Eles que não praticavam qualquer acto bárbaro ou estranho, mas que mostravam nas suas opiniōes, sentimentos helénicos e doces para com os deuses, viram-se constrangidos, declarada a guerra, a enterrar dois Gregos, um homem e uma mulher, e igualmente dois Gauleses.

Portanto, ter ou sentir disposições helénicas ou doces no culto aos deuses opóe-se ao procedimento dos bárbaros e aos actos e sacrifícios desumanos e cruéis.

É mais explícito ainda um passo da Vida de Lisandro, em que, após citar o decreto dos Tebanos a conceder

${ }^{16}$ Filipoimen 8.1: helleniken kai philanthropon politeian. 
asilo e apoio aos Atenienses que fugiam ao regime dos Trinta Tiranos (404-403 a.C.) e contra ele lutavam (27.6), Plutarco escreve:

E não se limitaram a votar medidas tão helénicas e tão humanas; apresentaram acçóes consentâneas com os decretos... ${ }^{17}$

É curioso e significativo o uso de hellenikos neste passo, porque são Gregos que actuam. O da Vida de Marcelo ainda poderia compreender-se que se diga "à maneira dos Helenos", porque estão em causa Romanos, mas no passo da Vida de Lisandro só pode ter o sentido de "simples, civilizado".

Em contraste com estas ocorrências de demotikos e hellenikos aplicados à pessoa moderada, simples e humana, o homem rude e violento é considerado oligárquico. Na obra de Plutarco são dezoito as ocorrências do termo oligarchikos, algumas das quais com o sentido de violento, grosseiro. Alguns exemplos: Coriolano, que, apesar da sua temperança (enkrateia), justiça e coragem, é rude e violento nas suas relaçôes com os concidadãos, aparece classificado de "insuportável, grosseiro (acharis) e orgulhoso ou "oligárquico" (1.3-4). Na comparação da sua conduta política de Coriolano com a de Alcibíades, Plutarco volta a utilizar quase as mesmas palavras, ao classificar a sua actuação de desagradável, orgulhosa

${ }^{17}$ Lys. 27.7. Cf. também Marc. 1.3 já citado acima, onde aparece sentido idêntico. 
e oligárquica ${ }^{18}$ e ao sublinhar que provocava o ódio do povo. Por outro lado somos informados de que Nícias, com um comportamento pouco humano e não democrático, mostrava uma atitude insociável e oligárquica, que parecia estranha.

Ou seja, o herói que é amável e humano recebe os epítetos de democrático e helénico, enquanto o que é rude e grosseiro é "oligárquico". Em contrapartida, quem é moderado, simples, afável, humano aparece designado por demótico, democrático, helénico. Os longos, mas elucidativos, caminhos das palavras.

Por outro lado, em associação com os termos philanthropia, demotikos e hellenikos, acima analisados, colocado lado a lado com eles e a designar a pessoa dotada - ou imbuída graças à educação - com as qualidades e virtudes que tais termos traduzem aparece o particípio perfeito médio-passivo pepaideumenos que significa 'intruído', 'bem formado', 'educado'. São vinte as ocorrências e todas elas sublinham o aspecto positivo das qualidades que se obtiveram através da educação. Pode ter o sentido de pessoa competente, hábil, preparado (cf. Lyc. 13.2 e 19.1), de "homem conhecedor das letras». ${ }^{19} \mathrm{~A}$ propósito de Luculo, Plutarco refere que o general preferia os louvores que derivavam da justiça e da humanidade (apo dikaiosynes kai philanthropias) aos que advinham dos sucessos militares, já que estes adquiriam-se apenas numa pequena parte graças ao exército e na sua maioria por efeito da tyche ou sorte, enquanto a justiça

18 Cor. 40.3.

${ }^{19}$ Dio 11.4: andra kai pepaideumenon peri logous. 
e a humanidade são fruto de um espírito doce e culto. ${ }^{20}$ Ao comparar as juventudes de Címon e de Luculo ( $L u c$. 44.4), informa que a do primeiro foi repreensível e desregrada, ao passo que a do segundo foi disciplinada e sensata (pepaideumene kai sophron).

$\mathrm{Na}$ Vida de Alexandre o particípio aparece associado à educação helénica. $\mathrm{O}$ jovem Estadista, ao conquistar Issos, por considerar mais digno de um rei vencer-se a si mesmo do que triunfar dos seus inimigos, não tocou nas mulheres, com excepção da viúva de Mémnon, Barsine, por se tratar de uma mulher que tinha uma educação grega (paideian Helleniken) e era de maneiras doces (ton tropon epieikes). ${ }^{21}$

Ocorrências com sentido idêntico poderemos encontar nos Moralia. Dou apenas um exemplo tirado da Consolação de Apolónio 102F-103A, em que se acentua que é próprio de homens bem formados e sensatos ( $p e-$ paideumenon kai sophronon andron) continuarem eles próprios diante da felicidade e guardar perante a desgraça uma atitude digna. ${ }^{22}$

Deste modo as Vidas fazem brilhar a paideia antiga - que também não está ausente das propostas dos Moralia -, propondo como ideal o de um herói pepaideumenos "instruído", culto, bem formado; são elas próprias obras primas de paideia destinada a aumentar a paideia dos leitores: os heróis aí biografados tornaram-se paradigmas e foram imitados ao longo dos tempos e

${ }^{20}$ Luc. 29.6.

${ }^{21}$ Alex. 21.9.

${ }^{22}$ Cf. ainda Moralia 117E. 
acabaram por ajudar a construir os valores da Europa. O pepaideumenos é o que, pela educação e formação, adquiriu doçura, moderação, sensatez, humanidade, simplicidade, ou seja se tornou praos, metrios, sophron, philanthropos, demotikos. 


\section{O DOCE AFAGO DA PHILANTHROPIA}

José Ribeiro Ferreira

A obra de Plutarco realça um conjunto de qualidades, ora de índole militar, ora de índole mais intelectual, que pode ser agrupado em quatro virtudes principais - coragem (andreia), inteligência (phronesis), justiça (dikaiosyne) e autodomínio (sophrosyne) - e a que já me referi em outro estudo. ${ }^{1}$ A pura coragem, no entanto, se não acompanhada da inteligência ou prudência e da previsão das situaçóes, aparece desvalorizada. Um bom exemplo, encontramo-lo num episódio relatado na Vida de Fábio Máximo (11.1-12.7), em que se exalta a capacidade do biografado em analisar a situação para tomar as decisóes ajustadas, em contraste com a atitude insensata do outro cônsul, Minúcio, que com ele dividia o comando do exército romano. A coragem imprevidente deste, o seu desejo de glória e a sua imprudência quase ia provocando um grave desaire frente aos Cartagineses, não fora a previdência e sensatez de Fábio que, no entanto, após a vitória sobre Aníbal, não teve uma palavra de censura para Minúcio. Este então conduziu os seus homens até ao acampamento do seu colega de comando e depôs diante dele as insígnias, felicitando-o pela dupla

${ }^{1}$ Vide J. Ribeiro Ferreira «Os valores de Plutarco e sua actualidade». As virtudes e valores mais significativos de Plutarco encontram-se estudados com algum pormenor por F. Frazier 1996 e C. Panagopoulos 1977 : 197-235. 
vitória conseguida: uma sobre Aníbal, graças à sua coragem (andreia) e a outra sobre ele, Minúcio, graças à sua prudência (euboulia) e bondade (Fab. 13.7).

Apesar disso, também a phronesis não merece o seu especial entusiasmo. Para ele, a justiça ou dikaiosyne obtém, em especial nas Vidas, quase sempre a primazia entre as demais e, associada de modo geral à sophrosyne para definir a conduta do bom e do mau governante, é elemento fundamental para o prestígio do homem público junto do povo e para a confiança deste $(C m 44$. 12):

De nenhuma outra virtude a fama e crédito provocam mais inveja do que os da justiça, pois sobretudo nela reside a influência e a confiança junto da multidão. ${ }^{2}$

Esta tendência para privilegiar a dikaiosyne e a sophrosyne talvez se deva ao facto de serem virtudes sociais que se aproximam da philanthropia - termo que se situa no campo semântico da característica doçura grega, tão exaltada pelo nosso autor. ${ }^{3}$

Consciente de que o dever da filantropia é tema frequente em Plutarco - encontramo-la, por exemplo,

${ }^{2}$ Cf também Flam. 11.4.

${ }^{3}$ Mostrou J. de Romilly 1979: 276 ss. que a doçura é fundamental na cultura grega e que em Plutarco atinge o ponto mais alto, na sua obra confluindo de certo modo todas as tradiçóes a ela relativas, todas as palavras para a designar, todas as formas de a conceber. Trata-se de uma qualidade que está presente em todo o lado, tudo comanda, e aparece como um ideal de vida essencialmente grego, traduzido no próprio vocabulário. 
exaltado no Consolo a Apolónio (120A $)^{4}$ - proponho-me precisamente fazer, neste trabalho, o estudo da ocorrência dos termos philanthropos e philanthropia e seus principais sentidos nas Quaestiones Convivales. ${ }^{5}$

Se, num passo da discussão sobre a prescrição atribuída a Pitágoras que proíbe o acolhimento de andorinhas em casa, o termo philanthropos surge com significado próximo do sentido etimológico - Plutarco estranha a prescrição $(727 \mathrm{C})$, por repelir ave tão inofensiva e humana ou 'amiga dos homens' (asines kai philanthropon), colocando-a ao mesmo nível das rapaces, selvagens e assassinas ${ }^{6}-$, as ocorrências mais comuns e frequentes são, todavia, aquelas em que os termos significam 'humanidade', trato 'humano' ou afável, como aliás seria de esperar. Assim ao discutir, logo no primeiro diálogo do Livro I (612E ss.), sobre a conveniência dos temas de filosofia nos banquetes, Plutarco, embora considere a necessidade de adequaçáo às ocasióes e às pessoas presentes, admite (614A-B) a existência de um género de narraçôes que se ajustam ao banquete, quer fornecidas pela história, quer retiradas dos actos da vida diária em que encontramos um significativo número de paradigmas de acçóes corajosas e magnânimas, muitos deles que aportam à filosofia e muitos outros à piedade; mas observa também que algumas dessas acçôes, úteis e humanas, conduzem à emulação. $\mathrm{O}$ sentido de «trato

${ }^{4}$ Sobre o assunto vide J. de Romilly 1979 : 293 ss.

${ }^{5}$ No seu conjunto, philanthropos e philanthropia ocorrem cerca de três centenas de vezes na obra de Plutarco, 17 das quais em Quaestiones Convivales.

${ }^{6}$ Faz parte da conversa 7 do Livro VIII (727B ss.). 
humano» aparece com alguma nitidez na conversa 8 do Livro VI, na qual, ao dissertar sobre a bulimia e a causa dela (693E ss.), se alude a um episódio relacionado com Bruto (694C): um nevão apanha o general romano no caminho de Durráquio - a grega Epidamno - para a cidade de Apolónia, pondo-lhe a vida em perigo, por ter perdido todos os que transportavam as provisóes. Então os seus próprios soldados, ao vê-lo debilitado, enregelado e prestes a sucumbir, sentiram-se na necessidade de acorrer às muralhas de Apolónia, que estava sitiada, e pedirem às sentinelas inimigas alimentos, com que de imediato reanimaram o seu comandante. Foi por essa razáo que, ao apoderar-se da cidade, Bruto tratou de forma humana (philanthropos) todos os seus habitantes. ${ }^{7}$

O sentido de 'humanidade' volta a surgir na conversa 4 do Livro VII (702D ss.), onde se discute a razáo de os Romanos de outros tempos deixarem sempre algum alimento na mesa quando se levantavam e, em especial, evitarem que uma candeia se apagasse. A determinada altura, Plutarco sublinha (703B) que esse costume constitui uma lição de humanidade (philan-

7 Plutarco narra o mesmo acontecimento e a mesma atitude na Vida de Bruto 25-25, verificados durante o esforço de Bruto na tentativa de se antecipar a Caio, irmáo de António, que avançava contra as forças de Vatínio, estacionadas nos dois referidos portos da Ilíria, embora a hipotermia do comandante romano, em Bruto 25 , ao contrário do que se deduz do passo das Quaestiones Convivales, ter-se-ia verificado na tomada de Durráquio e não diante de Apolónia. $\mathrm{O}$ episódio vem contado ou referido em várias fontes: e. g., Apiano, Civ III. 79, 321-323 e IV. 75, 317; Díon Cássio 47. 21.4-7; Cícero, Phil. X. 13 e XI. 26. 
thropias didaskalia), enquanto classifica de mesquinho o hábito de suprimir uma lâmpada, só porque já se não necessita dela, e apelida mesmo de ímpia a destruição do alimento, porque nos sobeja. E acrescenta de seguida que esse procedimento assenta, por um lado no dever de solidariedade aos outros, por outro também na gratidáo pelos objectos e coisas que nos são úteis.

Sentido idêntico - mas com uma conotação indecisa entre 'humano', 'generoso', 'benevolente' ou até 'grato' - aparece em dois exemplos da conversa oitava do Livro VII (711A-713F) que trata dos divertimentos apropriados ao banquete. Interrogado sobre o assunto, Diogeniano de Pérgamo, um amigo de Plutarco, póe algumas reservas aos diálogos filosóficos, como os de Platão; admite a adequação da música de cítara e de flauta, muito útil ainda para acalmar um festim agitado, no qual a discussão começa a azedar o ambiente (713A-E); afasta o teatro, mimos e fábulas (711E-712E), com alguma concessão apenas para as peças de Menandro (711B-C), autor em que se mistura o sério e o gracioso e em que as questóes amorosas ( $t a$ erotika) têm um tratamento honesto e elevado (712C-D): além de não encontrarmos o "amor pederástico", a sedução das donzelas termina, como convém, no casamento; e, nos casos de hetairas, as que são impudentes são abandonadas em consequência de censura ou de arrependimento dos jovens, enquanto as que são honestas e apaixonadas descobrem um pai legítimo ou com o tempo obtêm para o seu amor a humana ou benevolente complacência do respeito. Considera, além disso, que, embora compreenda não merecerem 
tais assuntos o interesse da generalidade das pessoas, náo estranha que o seu encanto e delicadeza, em conjunto, contribuíssem para moldar e ordenar os caracteres, de modo a torná-los semelhantes aos que são indulgentes e humanos (tois epieikesi kai philanthropois). ${ }^{8}$

Essa predisposição humana pode levar a uma atitude amável e atenciosa. É a do rei Filopapo, um dos convivas no banquete de comemoração da vitória de Sarápion, ensaiador do Coro da tribo ateniense de Leontis (628B): ${ }^{9}$ atento à conversa, ora dava a sua opinião, ora escutava a dos outros, náo menos por amabilidade (philanthropia) do que por curiosidade (philomatheian).

A atitude amável e generosa pode mesmo tomar o sentido e a forma de hospitalidade: um passo da conversa 2 do mesmo Livro I (617B) - que recorre a exemplo do Canto VII da Odisseia (vv. 169-170) em que Alcínoo, depois de referir que o rei dos Feaces manda levantar o seu filho Laomedonte, situado à sua direita, para aí instalar o suplicante Ulisses - sublinha que «sentar um

${ }^{8} \mathrm{O}$ termo epieikeia (ou o adjectivo epieikeios), cujo significado se aproxima de indulgência, é relativamente usual em Plutarco: ocorre mais de 100 vezes. Virtude de carácter mais pessoal, impregna o comportamento e implica contenção física, ao contrário de philanthropia que exprime uma qualidade que, como veremos, se volta para o exterior, para o convívio social.

${ }^{9}$ Embora o passo apenas especifique que Sarápion era o ensaiador do Coro vitorioso, é possível que o poema cantado - talvez um ditirambo - fosse da sua autoria. Poeta estóico, amigo de Plutarco, a quem este dedica o De E apud Delphos e que desempenha papel relevante no De Pythiae oraculis, compóe sobretudo poemas filosóficos de tendência moral. Vide R. Flacelière 1951: 323-327, D. Babut 1969 : 246-248. 
suplicante no lugar do que se ama (tou philomenou) é prova de cortesia e amabilidade» ou hospitalidade ( $p h i$ lanthropia).

Tem também sentido próximo a ocorrência numa alusão à recepção oferecida por Ágaton, para comemorar a vitória num concurso de tragédia - recepção que está na base do Banquete de Platão -, ao sublinhar que as boas regras da hospitalidade aconselham a que as pessoas levadas a um festim por amigos sejam recebidas com o mesmo modo humano e hospitaleiro dos convidados (ethei philanthropoi), como no referido diálogo aconteceu com Aristodemo levado por Sócrates para a festa de Ágaton (645F).

Um passo, sito na conversa 5 do Livro V (678C ss.), dedicada aos que convidam grande número de pessoas para jantar, admite que nessa hospitalidade há por vezes exagero, que se censura, tanto mais que se considera, pela boca do próprio Plutarco, que o banquete deve ter número de pessoas apropriado a permitir conversar, testemunhar mútua amizade, estabelecer conhecimento, e que, ultrapassado determinado limite, deixamos de ter banquete. Ditas estas palavras, o avô Lamprias concorda existir "algum exagero em matéria de filantropia» ou hospitalidade (678E), quando não se omite nenhum dos convivas possíveis e todos acorrem como se convocados para um espectáculo ou uma récita.

O sentido de philanthropos e philanthropia pode conter conotação de qualidade social, de sociabilidade, como sucede em algumas ocorrências de Quaestiones Convivales que passo a especificar. Surge, por exemplo, 
na conversa 10 do Livro II onde, a certa altura (643C-D), se considera que os banquetes de agora não devem ser a transposição das homéricas refeiçóes de soldados e combatentes, mas antes a exaltação do carácter humano ou sociabilidade (philanthropia) dos antepassados que respeitavam tanto a comunidade de lar e de tecto como também a de mesa e de refeição, em tão grande honra tinham qualquer reuniáo social.

Em 660A e 660B - passos que fazem parte do prólogo ao Livro IV, onde se acentua a importância do banquete no nascimento e consolidação da philia - a philanthropia ou sociabilidade aparece estreitamente associada à amizade. Plutarco, ao distinguir philia de eunoia (660A), sublinha que, se a primeira "se obtém com o tempo e por meio da virtude», a eunoia é favorecida pelos contactos e encontros que oferecem ocasióes propícias à amável persuasão e à benevolência. Observa depois que o banquete deve privilegiar a amizade, facilitada pelo vinho (660B): ou seja, permitir que se façam novos amigos e se conviva com os antigos, pois negligenciar estes prazeres é proceder como se a um banquete comparecêssemos pelo ventre e não pelo coração; ou, dito de outra forma, fôssemos apenas para comer e beber, sem participar no ambiente e no diálogo que deriva da influência humana e sociável da bebida e que termina em simpatia (eunoia 660B):

E o simposiasta que, pelo contrário, negligencia estas coisas anula em si a graça e o convívio e vem motivado pelo ventre e náo pela alma. De facto, o conviva não deve comparecer 
apenas pela carne, pelo vinho, pelas iguarias, mas também para partilhar a conversa, os divertimentos, a complacência que termina em simpatia. É que os ataques e pegas dos lutadores necessitam de poeira, enquanto nas colheitas da amizade o vinho favorece o contacto, quando se mistura com a palavra. A conversa, de facto, canaliza e passa do corpo para a alma a influência humana e benéfica que surge com a bebida.

E assim, sob os efeitos do vinho espalhado pelo corpo, a conversa durante o banquete (660C) impede que os simposiastas caiam em total modorra e solta ainda quem bebe dentro da medida, transformando-o em misto de alegria, de filantropia ou sociabilidade, de complacência, de modo que, devido ao vinho, se torna maleável e predisposto ao selo da amizade (sphragidi philias).

Esta predisposição para a sociabilidade ou philanthropia que o vinho possibilita aparece corroborada em passo da conversa que discute por que razão no início do banquete os convivas se sentem apertados e no final se passa o contrário. ${ }^{10}$ Segundo um dos simposiastas, o mais velho deles, dos dois presidentes que superintendem no banquete, a fome e Diónisos ou o vinho, a primeira náo se prende com tácticas, ao passo que o segundo é o mais excelente estratego de quantos se reconhecem (680A-B). Por isso, tal como Epaminondas, ao assumir o comando, salvou um exército, desmoralizado e desordenado devido à inexperiência dos generais, e restabeleceu as suas fileiras, também o deus do vinho, que

${ }^{10}$ Trata-se da questão 6 do Livro V (679E ss.). 
é Libertador e ordenador de Coros, restabelece a ordem entre os participantes no festim - de início amontoados como cães com fome - e traz depois a alegria e a filantropia ou sociabilidade.

É esse carácter social da refeição que, no prólogo do Livro VII (697C), teria provocado o dito «Eu hoje como, náo janto" pronunciado por um romano não identificado, mas que é todavia classificado como homem de espírito e pessoa sociável ou humana - philanthropos é o termo grego utilizado que de certo modo é aproximado de philophrosyne 'benevolência ou cordialidade que predispóe à amizade'. Pressupóe naturalmente a afirmação que o jantar, principal refeição do dia, implica ou exige companhia e aprazível cordialidade que traz a amizade. É por isso curioso, e significativo ao mesmo tempo, que Plutarco, atento e sensível a tudo o que seja solidariedade humana, na crítica que faz ao carácter solitário (De Frat. Am. 479C) utilize um composto de philanthropos com alfa privativo: aphilanthropos. Não menos elucidativo também que, para designar o homem social ou 'ser homem em conjunto', use o verbo synanthropeo (cf. Praec. ger. 823B), composto a partir de anthropos e da preposição syn, e que, segundo J. de Romilly, seja o primeiro a utilizá-lo. ${ }^{11}$

Em conclusão, os termos philanthropia ou philanthropos, e outros que com estes se relacionam, exprimem nas Quaestiones Convivales uma qualidade que, virada

${ }^{11}$ Vide F. Frazier 1979: 276. 
para o exterior, para o convívio social, para o contacto com os outros, se dilata até abraçar a humanidade inteira. Com ligação indissociável à civilização e ao helenismo, traduz sociabilidade, um modo de viver agradável e educado com os amigos, que tende no campo das relaçóes humanas para a philia (cf. Alc. 1.3; Pomp. 22.2), ${ }^{12}$ e, segundo as circunstâncias, pode tomar cores de amabilidade, de cortesia, de afabilidade, de gentileza, de hospitalidade, de bondade, de sociabilidade.

Talvez seja por essa razão que para Plutarco, em especial nas Vidas paralelas, o herói não é um homem só, mas sempre um responsável por outros, um chefe que deve velar pela salvação do exército e do estado, cuja prudência protege e cuja resolução galvaniza os outros; que a philanthropia se aproxima da dikaiosyne - a virtude suprema nas Vidas - mas também, como já mostrei em estudo anterior, do que exprimem adjectivos como demotikos e hellenikos ("democrático" e "helénico") e suas substantivaçóes - ou seja cultura, afabilidade, humanidade, benevolência, sociabilidade. ${ }^{13}$

${ }^{12}$ H. Martin Jr. 1961: 164-175. Na p. 174, considera que a philanthropia é a virtude por excelência do homem civilizado.

${ }^{13}$ Vide supra J. Ribeiro Ferreira 2008: "Demotikos e Demokratikos na Paideia de Plutarco" 


\section{Os valores de Plutarco e sua actualidade}

José Ribeiro Ferreira

Neste trabalho vou sobretudo basear-me nas Vidas Paralelas, por interessarem mais as virtudes em acção e por os heróis aí biografados constituírem paradigmas que sempre exerceram forte fascínio ao longo dos tempos. Não esquecerei evidentemente os Moralia, e para eles remeterei a cada passo. Mas foram sobretudo as Vidas - em que há uma grande coerência, quer no domínio técnico, quer na concepção moral - que influenciaram a cultura ocidental, ao oferecerem como paradigma os nobres e belos actos desses heróis, tantas vezes idealizados.

Plutarco, apesar de escrever no século I d. C., exalta uma idade de ouro da Grécia que termina, em Atenas, com a morte de Péricles e, em Esparta, com a de Lisandro (395 a. C.); de Roma realça as qualidades que a fizeram grande e poderosa. As Vidas paralelas povoam a Hélade e Roma de heróis, cujas virtudes convidam à imitação: frugalidade, simplicidade, honestidade, diligência, temperança, autodomínio, coragem, integridade, justiça, amor à pátria e amor à liberdade.

Este conjunto de qualidades - ora de índole militar, ora de índole mais intelectual - pode ser agrupado em quatro virtudes principais, tanto para as Vidas como para os Moralia: coragem (andreia), inteligência (phronesis), justiça (dikaiosyne) e autodomínio (sophrosyne). ${ }^{1}$

${ }^{1}$ Sigo aqui a classificação de F. Frazier 1996: 173-273 que analisa com pormenor a importância dessas quatro virtudes nas Vidas. C. Panagopoulos 1977:197-235 dá uma lista mais extensa: com 
Por exemplo, no De audiendis poetis - um tratado dedicado à educaçáo, à paideia - Plutarco recomenda que se ensine aos jovens a andreia, a sophrosyne, a dikaiosyne (30D) e a phronesis que, na opinião de Homero, "constitue la qualité la plus propre à un dieu et à un roi» $(32 \mathrm{~A})$.

A coragem - a que devemos associar tolma "audácia” - é a virtude colocada em primeiro lugar nas análises do carácter dos biografados, onde representa quer uma qualidade efectiva do herói, quer um ideal de que se alimentam os seus princípios e acção. ${ }^{2}$

Dentro do campo semântico da coragem situa-se o phronema, uma "disposição de espírito", que, frequentes vezes aparece associado a tolma, não é rara a sua intervenção em situações perigosas. É significativo o episódio da partida voluntária de Teseu para Creta, a fim de enfrentar o Minotauro (Thes. 17.2). Por altura do terceiro tributo a Cnossos, o povo cobre Egeu de amargas censuras, acusando-o de ser causador do mal, mas de nada sofrer nem se importar de os ver privados dos filhos.

nas inscriçóes citadas nas nos Tratados morais, comeia, como principais virtudes do cidadáo ideal do séc. I a. C., a eugenia (velho valor que é frequente na época arcaica grega), riqueza (ligada à generosidade), amor da glória, bons costumes, espírito de família, doçura, coragem, justiça, qualidades intelectuais, excelência.

${ }^{2}$ As cerca de sessenta especificaçóes de andreia nas Vidas, a que se deve juntar mais umas setenta ocorrências positivas de "audácia" (tolma), são sinal da importância que lhe é atribuída. São frequentes nas Vidas os actos de audácia admiráveis. Cf. Caes. 19.7, 20.9, 23.2, 32.3; Pyr. 15.8 e 30.8; Cam. 27.5; Them. 10.8 e 28.6. 
Tais lamentos tocaram Teseu que, por considerar não ser justo alhear-se mas ter o dever de partilhar a sorte dos seus concidadáos, se ofereceu voluntariamente para partir sem participar na tiragem à sorte. A todos os Atenienses pareceu tal grandeza de alma (phronema) coisa admirável, e ficaram satisfeitos com o seu devotamento ao povo. E Egeu, apesar de lhe pedir e suplicar, sempre o encontrou inflexível e constante na sua decisão.

Meio de alguém se distinguir e trampolim para quem aspira a uma carreira política, proporciona prestígio social, pois qualifica o herói como homem de guerra, capaz de servir a pátria em momentos de perigo; torna-se, contudo, insuficiente e mesmo ambígua fora do campo de batalha. ${ }^{3}$ Se é a virtude exigida no jovem e no soldado, não basta no general que, para Plutarco, têm necessidade de possuir outras qualidades:

Bruto [..... em caso de perigo, mostrava qualidades de general e de soldado desejoso de vencer, quer pela acçáo, quer pela inteligência. ${ }^{4}$

A distinção entre chefe e soldado tem implícita certa depreciaçáo da bravura puramente militar. A coragem, que é fundamental no ideal heróico, sofrera uma desvalorização na época clássica e no período helenístico, até adquirir um sentido que se aproxima do domínio de si, de força de alma, em detrimento da coragem guerreira. Não é por isso de estranhar que em Plutarco

${ }^{3}$ Vide F. Frazier 1996 : 199.

${ }^{4}$ Brut. 49.7. Cf também Sert. 4.3-5; Ant. 3.9-10. 
nos surja uma oscilação entre o elogio da coragem ao serviço da pólis e a desvalorização da pura audácia militar. Por exemplo, no prefácio da Vida de Pelópidas, impugna a confusão entre coragem e virtude, condena a pura audácia guerreira, distingue a coragem da louca temeridade e, depois de pôr em evidência os resultados nocivos desta última, conclui (2.9):

São estas as reflexóes que me vieram ao espírito, como introdução à vida de Pelópidas e à de Marcelo, grandes homens que morreram em combate de forma desrazoável.

Meritória no campo de batalha, a coragem - ou, melhor, a audácia — vê o seu valor inverter-se na cidade, onde se torna uma ameaça contra a ordem pública, a concórdia e a estabilidade, dada a possibilidade de causar assassínios, sedições, anarquia. ${ }^{5}$

Daí que tenda a concordar com a opiniáo de Françoise Frazier de que, nas Vidas, a coragem não aparece entre as qualidades fundamentais, ou até exigidas, ao homem político. ${ }^{6}$

Frequentemente associada à coragem surge a phronesis, que Plutarco considera «a mais divina e a mais real» de todas (Moralia 32A) e à qual dá o valor aproximado de sabedoria prática, de discernimento mesclado de prudência (cf. Them. 16.6; Fab. 17.4; Dion 6.4; Caes. 13. 6; Sólon 14.5). Para designar esta qualidade, ou pelo menos noçóes aproximadas, Plutarco recorre ainda a

5 Ver os passos citados em F. Frazier 1996: 202 n. 36.

${ }^{6}$ Vide F. Frazier 1996: 181-182 e 201-202. 
outros termos, como pronoia, a "previsão" que permite livrar algum de perigos e desgraças futuras (e. g. Lyc. 7.4 e 29.1), ou euboulia, a capacidade de reflectir e analisar a situação para tomar as decisóes mais apropriadas.

Elucidativo dessa ligação de coragem e inteligência como qualidades fundamentais do homem público é um passo da Vida de Numa que conta a razão pela qual foram erguidas estátuas a Alcibíades e a Pitágoras em Roma (8.20):

Eu mesmo ouvi dizer em Roma a muitas pessoas que os Romanos, quando um oráculo lhes ordenou que honrassem entre eles o mais sábio e o mais corajoso dos Helenos, ergueram no fórum duas estátuas de bronze, uma de Alcibíades e outra de Pitágoras. ${ }^{7}$

A capacidade de analisar a situação para tomar as decisôes ajustadas, vemo-la em evidência num passo da Vida de Fábio Máximo, onde aparece também associada à coragem. Minúcio, que com o biografado dividia o comando do exército romano, quase ia provocando, por desejo de glória e imprudência, um grave desaire frente aos Cartagineses, não fora a previdência e sensatez de Fábio (11.1-12.7) que, no entanto, após a vitória sobre Aníbal, não teve uma palavra de censura para Minúcio. Este então conduziu os seus homens até ao acampamento do seu colega de comando e depôs diante dele

7 Segundo Plínio, NH. 34.26, o oráculo emanara de Delfos e essas estátuas estariam colocadas in cornibus comitii, onde teriam permanecido até à época de Sila. 
as insígnias, felicitando-o pela dupla vitória conseguida: uma sobre Aníbal, graças à sua coragem (andreia) e a outra sobre ele, Minúcio, graças à sua prudência (euboulia) e bondade (Fab. 13.7).

Outra virtude importante - até pela tradição que possui em toda a cultura grega - é o auto-domínio, a sophrosyne, que apresenta, além disso, um carácter social. Esta sua característica já tinha sido sublinhada por Platão na República e no Górgias. ${ }^{8}$

Bom antídoto contra certos pontos fracos como luxúria, gosto da bebida, do dinheiro, do prazer, a sophrosyne associa à pura coragem um espírito de grandeza. Informa-nos Plutarco que Alexandre Magno praticou o autodomínio (sophrosyne) desde a infância, já que, de temperamento impulsivo e fogoso, mostrava-se indiferente aos prazeres corporais, desfrutando-os com muita moderação (Alex. 4. 8).

Mas nas Vidas a virtude suprema é a justiça que obtém quase sempre a primazia entre as demais. Associada de modo geral à sophrosyne para definir a conduta do bom e do mau governante, a dikaiosyne é, para Plutarco, elemento fundamental para o prestígio do homem público junto do povo e para a confiança deste $(C m 44.12)$ :

De nenhuma outra virtude a fama e crédito provocam mais inveja do que os da justiça, pois sobretudo nela reside a influência e a confiança junto da multidão.?

${ }^{8}$ No Górgias, por exemplo, Cálicles, um homem de desejo e de paixão, privilegia as virtudes de acção e rejeita «a moral definida pela justiça e pela sophrosyne» (491b-c).

${ }^{9}$ Cf. também Flam. 11.4. 
$\mathrm{Na}$ análise das quatro virtudes, Plutarco não manifesta entusiasmo pela phronesis, embora a considere a mais divina e real; a presença da andreia no retrato do homem de acção marca o impulso natural que gera doação total à cidade tanto na paz como na guerra; a dikaiosyne e a sophrosyne são virtudes sociais, aproximando-se a primeira da bondade e da philanthropia e traduzindo a segunda a simplicidade no dia a dia que permite náo se orgulhar da sua própria importância e permanecer acessível aos demais.

A análise feita e os passos citados deixam já perceber, subjacente, um princípio que, nas Vidas, tudo domina, equaciona todos os actos do herói: o dever de servir a cidade, de se lhe devotar, mesmo à custa da própria vida. Plutarco compraz-se em sublinhar essa dedicação do herói, como acontece com Aristides, Catáo e Publícola: ${ }^{10}$ a evocaçáo da primazia do bem público, em detrimento dos interesses pessoais, aparece em todas as Vidas Paralelas, com excepção das de Demétrios e de Êmenes. Precisamente num passo da Vida de Catão o Jovem colhemos a informação de que esse nobre romano não escolheu a carreira política por interesse mas por devotação à cidade (19.3):

Não foi pela fama, nem por cupidez, nem impensadamente, nem por acaso, como outros, que se dedicara aos assuntos da cidade, mas escolhera tal carreira como tarefa própria de um homem de bem, considerando ser seu dever trabalhar pelo bem público mais diligentemente do que a abelha no favo de mel.

${ }^{10}$ Vide F. Frazier 1996: 141. 
No caso de desacordo entre bem público e interesses particulares, o herói, mesmo lesado, deve calar o ressentimento, se o interesse da cidade o exigir. Ninguém deve contentar-se em gozar uma felicidade egoísta à margem da cidade, que só pode ser feliz, graças à sabedoria e dedicaçáo dos governantes. O legislador Licurgo, por exemplo, depois de fazer a assembleia aprovar que não alteraria a constituição na sua ausência, assegura-se junto do Oráculo de Delfos de que as leis com que dotara Esparta «eram boas e de que a cidade não deixaria de ter o mais glorioso destino» enquanto as observasse. Então envia a profecia aos seus concidadãos e deixa-se morrer de fome, para que eles continuassem ligados pelo juramento e não pudessem modificar a politeia espartana. Deu desse modo a prova máxima de doação pela cidade (Licurgo 29.8),

Persuadido de que o homem de estado tem de ser útil ao seu país, mesmo pelo sua morte, e de que o fim da sua vida não deve ser inútil, mas comportar mérito e eficácia. ${ }^{11}$

Mesmo em caso de morte de familiares, Plutarco sublinha que o herói deve manter a firmeza na dor e subordinar as dores e tristezas familiares aos negócios públicos: assim o fazem Demóstenes (22.5), Cleómenes (22.1-3), Paulo Emílio (36.7-9). O passo da Vida de Demóstenes expressa com clareza essa obrigação:

${ }^{11}$ Cf. também Lyc. 31.1. Relacionado com este assunto está o devotamento dos banidos, caso de Alcibíades (36.6) e dos Tebanos que lutam até à morte para não serem acusados de (Lys. 28. 12). 
Eu louvo Demóstenes por ter deixado às mulheres as lágrimas e os lamentos, relativamente às desgraças domésticas, para realizar o que ele julgava ser útil à cidade, e penso que é dever de um estadista e de uma alma corajosa manter-se sempre firme em questóes do bem comum e subordinar aos negócios públicos os actos e tristezas familiares. ${ }^{12}$

Embora figuras idealizadas, os heróis de Plutarco são pessoas humanas animadas pelas mesmas forças e paixôes de todas as épocas, como emulação, desejo de vencer e procura da glória e honra (philotimia), inveja. Plutarco admite a ambição, o desejo de honra, mas não uma ambição pessoal e egoísta, como é o caso da obsessão em Mário (Syl. 7.2). Pois essa philotimia, que é estimável, pode degenerar em paixão pelo poder (philarchia) que, exclusiva, é nefasta. Pompeu e César são bons exemplos dos males causados à cidade por essa ambição pessoal, quando se colocam os interesses pessoais e egoístas acima dos dessa cidade. ${ }^{13}$

Naturalmente essa ambição gera rivalidades, que são um motivo estruturante nas Vidas Paralelas, a ponto de conduzir à alteração dos factos, como acontece na

${ }^{12}$ A este tema se liga o do sacrifício dos seus pela pátria. É elucidativo o caso de Timóleon que, apesar do amor que tinha à família e de um dia ter salvo o irmão na frente de batalha, o manda executar, quando ele pela força tenta tornar-se tirano de Corinto (Timol. 4-5). Cf. aussi Cleom. 22.4-9.

${ }^{13}$ Plutarco sublinha com insistência essas ambiçóes dos dois estadistas romanos e seus malefícios: e. g. Pomp. 29.4, 30.6-7, 31.1-2, 70.1-2; Caes. 4.7-9, 7.1-4, 11.3-4, 56.7-9. Sobre o assunto vide F. Frazier $1996: 147-148$. 
Vida de Péricles. ${ }^{14}$ Considerando que tais rivalidades devem ser caladas no interesse da cidade, Plutarco exalta os heróis que são capazes e o sabem fazer. É essa doação que louva em Temístocles, quando, por ocasião da invasão de Xerxes, entrega a Esparta o comando das forças gregas aliadas, apesar de os Atenienses, que comandavam mais navios do que todas as demais cidades juntas, considerarem indigno deles obedecer a outros (Them. 7.3). Ou que sublinha em Aristides, quando este prescinde do seu lugar de estratego em favor de Milcíades, por reconhecer nele superioridade (Arist. 5.2-3); ou quando tudo faz para ajudar a pátria, durante a invasão de Xerxes, mesmo que dessa forma contribua para a glória de Temístocles que o havia ostracizado (Arist. 8.1).

Ambição e cupidez caminham frequentes vezes a par. Daí que a cada passo a sede de poder se conjugue com o amor às riquezes que pode procurar satisfazer-se à custa da cidade, causando a desgraça do estado. ${ }^{15}$ Crasso é disso um exemplo $(2.4 ; 6.8 ; 14.5 ; 18.1)$. No domínio do antagonismo entre interesse público e amor das riquezes, as Vidas fazem-se eco de dois confitos: oposição entre enriquecimento pessoal e interesse da cidade; e oposição entre gestão do património herdado e administração do estado.

Plutarco condena, sem margem para dúvidas, os que enriquecem à custa dos cargos públicos que ocupam

${ }^{14}$ Vide F. Frazier 1996: 103.

${ }^{15}$ A união de paixão pelo poder e de desejo do dinheiro é rejeitada nos Preceitos políticos 26. 798E-F e e vários passos das Vidas: Arist. 3.4; Cm. 19.3 (vide supra p. 103); Pomp. 31.8; Brut. 29.5. 
e sublinha a necessidade de incorruptibilidade do governante (Preceitos politicos 26. 819D-E):

Despoja-te, de imediato, do amor ao dinheiro e às riquezas, como se se tratasse de um ferro cheio de ferrugem e de uma doença de alma.

Se Fócion é um estadista que sobressai pela isenção em questôes de dinheiro (18 e 21.3-5), o exemplo mais conhecido é o de Péricles, cuja autoridade não lhe vinha apenas da sua força persuasiva, mas da estima e confiança "que inspirava um homem manifestamente e sem qualquer dúvida incorruptível e acima de todas as riquezas». ${ }^{16}$ Demóstenes oferece um exemplo contrário (25.3-5). ${ }^{17}$

Com esta questão se liga a gestão e conservação, transmissáo desses bens familiares. Sobre a legitimidade de dedicar tempo a essa tarefa ou negligenciá-la por inteiro, consagrando todos os esforços à política, Plutarco apresenta uma posição oscilante entre o desprezo do filósofo e um realismo social. A comparaçáo das Vidas de Aristides e de Catấo oferece argumentos de apoio às duas posiçóes. ${ }^{18}$

${ }^{16}$ Per. 15.3. Tucídides 2. 65.8 dá-nos informação idêntica.

${ }^{17}$ Esta necessidade de integridade aparece traduzida nas Vidas por diversos temas ou fórmulas recorrentes: "ter mãos limpas" (Per. 8.8; Arist. 4.3, 4.6-7 e 24.7); tudo regular de modo puro e justo (Arist. 24.2); não enriquecer uma dracma servindo-se dos cargos públicos (Arist. 24.2; Paulo Emílio 4.4 e 23.10); recusa dos presentes ou aceitá-los na justa medida (Cm 15; Phoc. 18; Luculo 2.7-8). A recusa é ilustrada na Vida de Philipoimen 15.2 e 15.9. Para mais pormenores sobre o conflito entre o interesse público e o amor das riquezas vide F. Frazier 1996:149-153.

${ }^{18}$ Sobre o assunto vide F. Frazier 1996: 154-155. 
A conciliação parece ter sido conseguida por Péricles que, apesar de durante mais de quinze anos ter sido eleito sucessivamente para o cargo máximo de estratego e se ver na necessidade de dedicar o seu tempo ao governo da cidade, não descurou os bens adquiridos (16. 3):

Nunca se deixou corromper pelas riquezas, náo por de todo se desinteressar do dinheiro, mas por não querer deixar perder por negligência a riqueza que legitimamente herdara do pai, nem se ver envolvido em diversos actos e perdas de tempo, imaginou um modo de administrar a casa que lhe parecia ser o mais cómodo e o mais exacto.

Como vimos as rivalidades, omnipresentes nas Vidas, têm por acicate a ambição, mas possuem também um árbitro, a opinião pública. A impopularidade aparece assim como um perigo consubstancial para o homem público. Daí que Plutarco sublinhe os erros que, sendo criticáveis, devem ser evitados. Mas, em contrapartida, vê também o estadista como um pedagogo dessa mesma opiniáo da multidáo. ${ }^{19}$

Assim sendo, a primeira qualidade de um homem de Estado será a capacidade de resistir e de se impor não só aos adversários, mas também à opinião. Tem de ser psicólogo e pedagogo, procurando imitar o modo como a divindade governa o mundo (Phocion 2. 9):

${ }^{19}$ Vide F. Frazier 1996: 115-116 e 121 ss. 
Diz-se que o deus governa o mundo, não por meio da violência, mas conduzindo docemente a necessidade pela persuasão e pela razão.

Daí que o dirigente não deva tratar a vontade popular com rigor duro e severo, mas deva, pelo contrário, (Phocion 2. 8)

Saber fazer concessóes aos que se deseja persuadir, dar-lhes o que lhes agrada para exigir deles o que é útil e uma forma de governo salutar (os homens entregam voluntariamente e com doçura muitos dos serviços solicitados, se não forem levados de forma despótica e violenta.

Péricles é um dos mais acabados exemplos de bom estadista que não se deixa arrastar pelas paixóes do povo, mas que o sabe conduzir pela persuasão e, pelo seu governo, que o guia nos momentos de perigo, como o piloto salva o navio nas tempestades (15.1-2):

A maior parte do tempo conduzia pela persuasão e pelo conselho o povo que o seguia de livre vontade; mas por vezes, quando o povo também se revoltava, o estadista então segurava as rédeas e levava-o a ver o seu verdadeiro interesse e assim o dominava. ${ }^{20}$

${ }^{20}$ Foi este o procedimento de Péricles nos primeiros anos da Guerra do Peloponeso, como narra Tucídides no livro II. 65.9, passo em que Plutarco sem dúvida se inspira. Para outros passos de heróis que exercem a pedagogia do povo vide F. Frazier 1996: 121-123. 
Do que até agora foi dito e das narrações, quer de cenas de guerra, quer de tempos de paz, pode concluir-se que, nas Vidas paralelas, o herói não é um homem só, mas sempre um responsável por outros, um chefe que deve velar pela salvação do exército e do estado, cuja prudência protege e cuja resolução galvaniza os outros.

É neste contexto que entra a característica doçura grega, «essenciellement une vertu de sociabilité, de tolérance et d'indulgence» (p. 328), como a define J. de Romilly - que no livro La douceur dans la pensée grecque (Paris, 1979) faz uma pormenorizada análise dessa qualidade grega, que se aproxima da clementia romana, mas que com ela se não confunde, por ser mais ampla. Considera a helenista francesa que os textos atestam com clareza a sua sobrevivência e que, nos fins da literatura grega, com Plutarco, se encontra o apogeu dessa noção de doçura. Presente em todo o lado na obra do filósofo de Queroneia, comanda tudo e aparece como um ideal de vida essencialmente grego que se traduz no próprio vocabulário: praotes "mansidão", "doçura"; epieikeia (ou o adjecttivo epieikeios) que se aproxima de "igualdade" ou indulgência; philanthropia ou philanthropos "humanidade". ${ }^{21}$ As duas primeiras, virtudes de carácter mais pessoal, impregnam o comportamento e traduzem contenção física. ${ }^{22}$ A philanthropia, pelo

${ }^{21}$ Os termos praotes (contabilizando as palavras da família) e epieikeia (ou o adjecttivo epieikeios) aparecem mais de 100 vezes cada um; philanthropia e philanthropos são utilizados cerca de 50 vezes.

${ }^{22}$ Quanto à praotes - que é antes de mais uma resistência interior à cólera e à violência, aos prazeres (cf. Brut. 1.3) — o autor 
contrário, exprime uma qualidade que se volta para o exterior e se dilata até abraçar a humanidade inteira. Indissociavelmente ligada à civilização e ao helenismo, traduz um modo de viver agradável e civilizado com os amigos; pode tomar, segundo as circunstâncias, as cores de afabilidade, cortesia, liberalidade, gentileza, bondade ou clemência; e tende, no campo das relaçôes humanas, para a philia. ${ }^{23}$ Assim tem ligações estreitas com outra característica saliente dos heróis de Plutarco, a charis que exprime o tratamento agradável, ameno, recíproco entre o que é beneficiado e o que beneficia. ${ }^{24}$

Qualidade e tendência pessoal que se pode educar, a doçura intervém praticamente em todos os aspectos da vida do herói: aparência, comportamento, modo de vida ou acçóes.

Relacionado com a noçáo de doçura e de certo modo uma consequência das virtudes anteriormente referidas, está o ideal de moderação expresso por Plutarco através da metriotes que se apresenta menos como uma tendência do carácter do que como uma submissão voluntária a uma norma exterior. Situa-se no domínio da sophrosyne e leva a não alimentar pensamentos acima da natureza humana, a evitar a hybris e pensamentos orgulhosos (megaphronein), a refrear todos os excessos. Essa era, por exemplo, uma qualidade de Díon, sempre «modeste dans ses vêtements, son service et sa table» (Dion

mostra que ela cobre o domínio físico e moral, reveste aspectos intelectuais e se associa à legalidade.

${ }^{23}$ Jr. H. Martin 1961: 164-175. Na p. 174, considera que a philanthropia é a virtude por excelência do homem civilizado.

${ }^{24}$ Vide C. Meier 1987: 37. 
52.3); e moderado foi o comportamento de Camilo no desempenho das diversas magistraturas para que foi nomeado (Cam. 1.4):

ele procedia de tal modo que partilhava o poder, mesmo em casos em que era comandante único, mas a glória era particular, mesmo quando comandava em conjunto com outros. No primeiro caso, a moderação (metriotes) permitia-lhe exercer o poder sem causar inveja; no segundo, a inteligência (phronesis) assegurava-lhe o primeiro lugar sem contestação. ${ }^{25}$

A vitória na guerra e a captura de prisioneiros são a ocasião propícia para a prática da doçura que se afirma então pela humanidade e clemência, por certa retenção: do vencedor que se encontra em posição de força ou de quem possui razóes de irritação e de ser severo. É neste âmbito que podemos enquadrar também o tema do vencedor aflito ou dos remorsos que sente por ter de saquear e destruir cidades, fazer prisioneiros; com ele procura Plutarco sublinhar o valor moral das suas personagens. Por exemplo, adquire grande relevo na Vida de Alexandre, onde a insistência nos remorsos e a humanidade do jovem imperador para com as cativas persas várias vezes referidos (21.2 e 30.1-12) compensam e procuram desculpar as acçóes mais controversas do rei: destruição de Tebas (13.3), a morte em cativeiro da rainha da Pérsia (30.1), o incêndio de Persépolis (33.3) e outros actos de violência.

${ }^{25}$ Cf. também Cam. 24.4; Publ. 10.8 e 12.1 
Por outro lado, ao abrir-se aos outros, a doçura é uma qualidade que espalha em torno de si a paz. A Vida de Numa refere que, no tempo deste rei, a guerra desapareceu de Roma e nunca se viu o templo de Jano aberto. E logo de seguida acrescenta (Numa 20.4):

O povo romano náo foi o único que se sentiu abrandar, seduzido oela justiça e doçura (praotes) do rei, mas também as cidades que estavam à sua volta, como se levados por uma brisa ou por um vento salutar que de Roma sopravam, começaram a mudar os costumes, a desejar viver todos com boas leis e em paz, cultivar a terra, alimentar os filhos com tranquilidade, venerar os deuses.

Ainda neste contexto de actuação humanizada do herói se situa o recurso ao tema do destruidor de cidades contra vontade - ou seja, do vencedor aflito. Plutarco procura desculpar os seus heróis da destruição de uma cidade, recorrendo à pressão e às exigências do exército. É o que acontece na tomada de Siracusa por Marcelo que, felicitado pelos seus oficiais como vencedor, sente uma grande afliçáo pelo destino da cidade (19.2-6 e 12):

Mas ele próprio, que tinha visto a cidade de um ponto elevado e tinha observado tudo em sua volta, a sua grandeza e a beleza, chorou copiosamente, aflito com o pensamento do que is acontecer [.....] E foi contravontade e por ter sido constrangido que ele consentiu deixar o exército apropriar-se das riquezas e dos escravos. Quanto aos homens livres, proibiu que lhes tocassem; interditou que matassem, 
maltratassem ou reduzissem à escravatura algum siracusano. Entretanto, além de manifestar uma opinião assim tão moderada, considerava a cidade digna de lamento.

Em Plutarco encontramos frequentes vezes sublinhada a ideia de que a humanidade do herói para com os vencidos ou os subordinados é muitas vezes mais eficaz do que a violência e a dureza. Não são raros os exemplos de vencidos que aceitam o domínio dos vencedores, ou até se lhe submetem voluntariamente, em consequência do tratamento humano que deles recebem. É essa doçura que vai estar na origem da Simaquia de Delos: os Gregos, que se haviam aliado para enfrentarem unidos a invasão de Xerxes, entregam o comando das forças aos Espartanos; mas, tratados por estes com rudeza, sobranceria, de modo insuportável, aderiram voluntariamente à hegemonia ateniense, seduzidos pelo tratamento amável de Aristides e Címon (Arist. 23.1):

O próprio Aristides os tratava com doçura e humanidade e incitava Címon a mostrar-se complacente e afável com eles nas expediçôes militares. Desse modo, sem precisar de hoplitas, nem de navios, nem de cavaleiros, à custa de nobreza de sentimentos e de diplomacia, retirou aos Lacedemónios a hegemonia. ${ }^{26}$

A mesma amenidade, doçura e cortesia presidem aos contactos de Roma com a Hélade. Flaminino tratou os Gregos com humanidade e, nos seus contactos com

${ }^{26}$ Em Cim. 6.2, Plutarco diz sensivelmente o mesmo a respeito do Címon. 
eles, recorreu à persuasão, à negociação em vez da guerra, à justiça. Deu assim de Roma uma visão positiva e facilitou o domínio (Flam. 2.5). Essa sua actuação conquistou os Helenos que viram nele o seu libertador (5.7):

um homem jovem, de trato afável, entendendo e falando grego, amante da honra e da verdade ; eles sentiam-se seduzidos e, ao deixá-lo, encheram as cidades de sentimentos de indulgência a seu respeito e ficaram seguros de que teriam nele um defensor da sua liberdade. ${ }^{27}$

Mas, apesar de conquistadora, Roma recebeu a cultura e muitos dos valores da Grécia. Como refere Horácio (Epist. 2.1 156-157),

Graecia capta ferum uictorem cepit et artes intulit agresti Latio. [...]

Para Plutarco, o império romano é cadinho e garante da perenidade dessa civilização greco-romana que se foi formando. É curioso e significativo o seguinte passo da Vida de Marcelo (1.3):

Era moderado, humano, interessado pela cultura e letras gregas, a ponto de honrar e admirar os que se lhe dedicam com zelo, mas ele próprio, por falta de tempo, náo as pode exercitar e aprender tanto quanto era seu desejo.

Portanto homem da cidade, o herói de Plutarco não é somente o servidor dessa cidade, mas é também

\footnotetext{
${ }^{27}$ Cf. também 15.3, 17.1.
} 
a encarnação de todos os seus valores: humano, polido, amável, cortês, culto, benevolente, romano ou grego uma noção que está próxima do ideal do homem da cidade e que, segundo Frazier, corresponde ao próprio ideal de civilização. ${ }^{28}$ Não estamos longe afinal de uma visão da doçura como virtude democrática. Plutarco ao homem de modos simples e afáveis dá-lhe o apelido de demotikos ("amigo do povo") ou "democrático", associando a palavra a philanthropia. Por exemplo, para designar a simplicidade e afabilidade de Agesilau usa os termos demotikos e philanthropos (Ages. 1.5). Na Vida de Luculo (44.5), ao comparar as refeiçóes de Luculo com as de Címon, contrapóe a do primeiro, faustosa como a de um sátrapa, à do segundo, democrática (demokratikê) e generosa (philanthropos). Por outro lado, para designar actos humanos e benevolentes, aparece a associaçáo dos adjectivos "helénico", doce (praos), humano (philanthropos), como está bem explícito neste passo da Vida de Lisandro (Lys. 27.7):

E eles não se limitaram a votar medidas tão gregas (hellenika) e tão humanas (philanthropia). ${ }^{29}$

Pelo contrário, o homem rude e violento é considerado oligárquico. Coriolano, que, apesar da sua temperança, justiça e coragem, é rude e violento, pelo que classificado de "insuportável, grosseiro (acharis) e orgulhoso ou "oligárquico" (1.3-4). Ou seja, o herói

${ }^{28}$ Vide F. Frazier 1996: 274.

${ }^{29}$ Cf. também Marc. 1.3. 
que é amável e humano recebe os epítetos de democrático e helénico, enquanto o que é rude e grosseiro é "oligárquico". Os longos, mas elucidativos, caminhos das palavras.

Embora homem integrado no império romano, Plutarco pensa que serve um ideal grego; defende a civilização que, por essência, é grega e que transparece em muitos dos seus heróis: cultura, afabilidade, humanidade, benevolência, sociabilidade — tudo o que se pode exprimir pela palavra philanthropia. ${ }^{30}$-, valores que impregnaram profundamente a cultura romana.

As Vidas fazem brilhar a paideia antiga, propondo como ideal o de um herói pepaideumenos "instruído", culto e sendo elas próprias obras primas de paideia destinada a aumentar a paideia dos leitores: os heróis aí biografados tornaram-se paradigmas e foram imitados ao longo dos tempos.

A geraçáo dos revolucionários franceses de 1789, na leitura dos autores antigos, era convidada a admirar as virtudes e liberdades republicanas da Grécia e de Roma e incitada a seguir o exemplo, dos seus heróis e governantes que encontravam retratados em Plutarco. Brissot de Warville, um líder da Gironda, conta que, no último ano de estudante o seu desejo de fama e os seus sonhos eram satisfeitos sobretudo na leitura de Plutarco e que ansiava assemelhar-se a Fócion. Mme Rolland confessa que o contacto com Plutarco a tornou republicana e que, em criança e na juventude, as Vidas

${ }^{30}$ Vide F. Frazier 1996: 280-281. 
Paralelas, que ela chegava a levar para a igreja em vez do livro de oraçóes, a transportavam para o passado da Grécia e de Roma, a faziam identificar-se com os heróis aí biografados e compartilhar as suas paixóes; lamentava mesmo não ter nascido espartana ou romana.

Para muitos dos revolucionários franceses, o ideal era a virtude severa das antigas Grécia e Roma, em especial de Esparta - uma virtude concebida segundo o modelo de Plutarco, composta de austeridade, simplicidade, doação, caridade, incorruptibilidade e devoção à pátria. 


\section{Bibliografia}

\section{EdIÇÓES, TRADUÇÓES E COMENTÁRIOS}

C. Ampolo e M. Manfredini (21993), Plutarco. Le Vite di Teseo e di Romolo. Milano.

J. R. Ferreira e M. de F. Silva (1994), Heródoto. Histórias. Livro $1^{\circ}$. Lisboa.

F. Fuhrmann (1978), Plutarque. Oeuvres Morales. Tome IX. Paris.

M. Manfredini e D. P. Orsi (1996), Plutarco. Le Vite di Arato e di Artaserse. Milano.

A. Pérez Jiménez (1985), Plutarco. Vidas Paralelas. I TeseoRómulo, Licurgo-Numa. Madrid.

\section{EsTUdOS}

C. Ampolo (2002), "La paideia degli eroi fondatori l'educazione e la giovinezza nelle Vite di Teseo e di Romolo", in J. R. Ferreira (coord.), Plutarco educador da Europa. Porto, 281-292.

D. Babut (1969), Plutarque et le Stö̈cisme. Paris.

H. Bacon (1961), Barbarians in Greek Tragedy. New Haven.

H. Bauzà (2002), "Humanismo y acciones en Las Vidas de Plutarco", in J. R. Ferreira (coord.), Plutarco educador da Europa. Porto 181-196. 
F. Becchi (1999), "Plutarco fra platonismo e aristotelismo: la filosofia comme paideia dell'anima", in A. Pérez Jiménez, J. García López, R. M. Aguilar (eds.), Plutarco, Platón y Aristoteles. Actas del V Congreso Internacional de la I.P.S. Madrid, 25-43.

F. E. Brenk (1975),"The Dreams in Plutarch's Lives", Latomus 34.2 336-349.

P. Briant (1989), "Histoire et idéologie: les Grecs et la 'décadence perse' ", in Mélanges P. Lévêque II. Paris, 33-47.

(1994), "L' histoire achéménide: sources, méthodes, raisonnements et modèles", Topoi 4/1 109130 .

(1996), Histoire de l'empire perse. De Cyrus à Alexandre. Paris.

B. Cunliffe (1988), Greeks, Romans, and Barbarians: Spheres of Interaction. London.

Th. Duff (2003), "Plutarch on the Childhood of Alkibiades (Alk. 2-3)”, PCPS 49 89-117.

H. Erbse (1956), "Die Bedeutung der Synkrisis in den Parallelbiographien Plutarchs", Hermes 84 398424.

M. C. Fialho (2002), "Teseu em Plutarco à luz da tradição", in J. R. Ferreira (coord.), Plutarco educador da Europa. Porto, 67-79.

R. Flacelière (1951), "Le poète stoïcien Sarapion d' 
Athènes, ami de Plutarque”, REG 64 323-327 (1937), De Pythiae oraculis. Paris.

F. Frazier (1988), "À propos de la philotimie dans les Vies. Quelques jalons dans l'histoire d'une notion", RPh 67.1 109-127.

(1996), Histoire et morale dans les Vies parallèles de Plutarque. Paris. 173-2.

P. Georges (1994), Barbarian Asia and the Greek Experience: from the Archaic Period to the Age of Xenephon. Baltimore.

L. Guillén Selfa (1997), "Plutarco. Moralidad y tragedia”, in C. Schrader, V. Ramón, J. Vela (eds.), Plutarco y historia. Actas del $V$ simposio español sobre Pluraco. Zaragoza, 20-22 de Junio de 1996. Zaragoza, 241-253.

J. P. Hershbell (1988), "Plutarch's Portrait of Socrates", ICS 13 365-381.

H. Herther (1936), “Theseus der Ioner”, RhM 85177 239.

T. Long (1986), Barbarians in Greek Comedy. Carbondale.

M. C. Magán (1999), "Embriaguez y vida disoluta en las Vidas” in J. G. Monts Cala, M. Sanchez Ortiz de Landaluce, R. J. Jesus Gallé Cejudo (eds.), Plutarco, Dioniso y el vino. Actas del VI Simposio Español sobre Plutarco. Madrid, 171-180. 
Jr. H. Martin (1961), "The concept of 'philanthropia' in Plutarch's Lives”, AJPh XX 164-175.

C. Meier (1987), La politique et la grâce. Paris.

A. G. Nikolaidis (1986), "Hellenikos-Barbarikos: Plutarch on Greek and Barbarian Characteristics", WS 99 [N. F. 20] 229-244.

(1997), "Plutarch's Criteria for Judging his Historical Sources”, in C. Schrader, V. Ramón, J. Vela (eds.), Plutarco y historia. Actas del V simposio español sobre Pluraco. Zaragoza, 20-22 de Junio de 1996. Zaragoza, 329-341.

D. P. Orsi (1988), "La rappresentazione del sovrano nella Vita di Artaserse plutarchea”, AncSoc 19 135-160.

C. Panagopoulos (1977), "Vocabulaire et mentalité dans les Moralia de Plutarque”, DHA 3 197-235.

Ch. Pelling (ed.) (1997), Greek Tragedy and the Historian. Oxford.

A. Pérez Jiménez (1973), "Atitudes del hombre frente a la tyche en las Vidas Paralelas de Plutarco", BIEH 7 101-110.

J. de Romilly (1979), La douceur dans la pensée grecque. Paris.

D. A. Russell (1972), Plutarch. London.

T. S. Shmidt (1999), Plutarque et les barbares: la réthorique d'une image. Louvain. 
C. Soares (2005), "A visão do 'outro' em Heródoto", in M.C. Fialho, M. F. Silva, M. H. Rocha Pereira (eds.), Génese e consolidaçâo da ideia de Europa. Vol. I: de Homero ao fim da época clássica. Coimbra, 95-176.

Ph. Stadter (1988): "The Proems of Plutarch's Lives", ICS 13.2 (1988) 275-295.

(2000), "The Rhetoric of Virtue in Plutarch's Lives", in Luc Van der Stock (ed.), Rhetorical Theory and Praxis in Plutarch. Acts of the IV. International Congress, International Plutarch Society, Leuven, Belgium, July 3-6, 1996. Leuven, 493-510.

(2003/2004), “Mirroring Virtue in Plutarch's Lives", Ploutarchos, n.s. 1 89-96.

S. C. R. Swain (1922), "Plutarchean Synkrisis", Eranos $90.2101-111$.

(1989),"Plutarch: Chance, Providence and History”, AJPh 110 272-302.

H. J. Walker (1995), Theseus and Athens. Oxford. 
